Review

\title{
Current Status of Biomarkers for Prostate Cancer
}

\section{Vicki M. Velonas ${ }^{1}$, Henry H. Woo ${ }^{2}$, Cristobal G. dos Remedios ${ }^{1, *}$ and Stephen J. Assinder ${ }^{1, *}$}

1 Bosch Institute, the University of Sydney, Sydney 2006, Australia;

E-Mail: vve19215@uni.sydney.edu.au

2 Sydney Adventist Hospital Clinical School, the University of Sydney, Sydney 2006, Australia;

E-Mail: hwoo@urologist.net.au

* Authors to whom correspondence should be addressed;

E-Mails: cris.dosremedios@sydney.edu.au (C.G.R.); stephen.assinder@sydney.edu.au (S.J.A.);

Tel.: +61-2-9351-3209 (C.G.R.); +61-2-9036-3614 (S.J.A.);

Fax: +61-2-9351-6546 (C.G.R.); +61-2-9351-2058 (S.J.A.).

Received: 19 April 2013; in revised form: 13 May 2013 / Accepted: 14 May 2013 /

Published: 24 May 2013

\begin{abstract}
Prostate cancer (PCa) is a leading cause of cancer-related death of men globally. Since its introduction, there has been intense debate as to the effectiveness of the prostate specific antigen (PSA) test as a screening tool for PCa. It is now evident that the PSA test produces unacceptably high rates of false positive results and is not prognostic. Here we review the current status of molecular biomarkers that promise to be prognostic and that might inform individual patient management. It highlights current efforts to identify biomarkers obtained by minimally invasive methods and discusses current knowledge with regard to gene fusions, mRNA and microRNAs, immunology, and cancer-associated microparticles.
\end{abstract}

Keywords: PSA; genomics; antibody microarrays; diagnostic biomarkers; genomics; prostate cancer; proteomics

\section{Introduction}

Prostate cancer ( $\mathrm{PCa})$ is the second most common cause of male cancer-related deaths and the most common male non-cutaneous malignancy in the Western world [1]. Recent statistics from the Prostate Cancer Foundation of Australia [2] demonstrate that just as many men die each year from PCa as 
women die from breast cancer. In Australia alone 120,000 men live with PCa, 20,000 new cases are diagnosed per year and approximately 3,300 will die each year [2]. Globally, this equates to a PCa related death every four minutes. The rate of diagnosis dramatically increased over the past decades in part due to an ageing population, increased awareness of $\mathrm{PCa}$, and the introduction of the prostate specific antigen (PSA) test [3].

Current diagnosis and "informed" treatment decisions for PCa involve digital rectal examination (DRE), PSA and subsequent biopsies for histopathological staging [4]. However, each procedure has its shortcomings and, in practice, has led to the over-treatment of low-risk patients [5], unnecessary biopsies and non-essential radical prostatectomies [6,7]. Current emerging biomarkers aim to enable the determination of an appropriate treatment strategy for individual patients, detect advanced disease at an earlier stage, and predict metastatic cancer and re-occurring disease following prostatectomy.

There is some lack of agreement on the characteristics of clinically significant or insignificant PCa. This has led to difficulties and variations among urologists when identifying patients for further treatment. By definition, clinically insignificant PCa does not contribute to PCa mortality. The main problem that faces us today is over diagnosis and treatment of patients with this form of disease (indolent $\mathrm{PCa}$ ).

The National Cancer Institute defines a biomarker as "a biological molecule found in the blood, other body fluids, or tissues that is a sign of a normal or abnormal process or of a condition or disease" [8]. The ideal biomarker should screen for the disease and its progression, identify high-risk individuals, predict recurrence, and monitor response to treatments. It should be economical, consistent, non-invasive, easily accessible, and quickly quantifiable. This review discusses the shortcomings of the PSA test with regard to these ideals, and summarizes the most promising emerging biomarkers for PCa and the need to develop a test for $\mathrm{PCa}$ that can distinguish between healthy patients, benign prostatic hyperplasia (BPH), clinically insignificant cancer (indolent PCa) and clinically significant PCa (re-occurring metastatic, and castration resistant prostate cancer (CRPC)).

\section{Prostatic Acid Phosphatase and Prostate Specific Antigen Tests}

Prostatic acid phosphatase (PAP) is a glycoprotein dimer produced predominately by the prostate and was initially used as a serum biomarker for the detection of metastatic PCa [9]. Unfortunately, PAP has a low sensitivity for detecting localized disease [10] and was replaced as a test following the discovery [11] and development of the prostate specific antigen (PSA) test. PSA is a $33 \mathrm{kDa}$ serine protease (kallikrein-3) that is secreted by the epithelial cells of the prostate. In normal prostate, PSA is secreted from the prostatic epithelium into the secretory ducts to contribute to the seminal fluid. However, in PCa, disruption of the basal-cell layer allows PSA to "leak" into the circulation resulting in elevated serum levels of PSA. Whilst PSA is prostate enriched it is not necessarily indicative of disease [12]. As such, levels of serum PSA may be raised by non-cancer related BPH, prostatitis, diet alterations, medications and environment [13]. Furthermore, PSA does not distinguish between stages of PCa and, significantly, does not identify metastatic PCa with the sensitivity and specificity required to make accurate therapeutic decisions [14]. Since the implementation of PSA screening among the ageing population, it has reduced the average age of PCa diagnosis from 70 to 71 years of age to 67 years of age [15]. The widespread use of PSA as a screening tool has been partly responsible for the 
rapid increase in PCa diagnoses in the past two decades. Although mortality associated with PCa has decreased over the years, it is uncertain whether it is due to the introduction of PSA screening or to the advances and efficacy of current PCa treatments [16].

Unfortunately, the PSA test can result in false positives. When a PSA threshold of $4 \mathrm{ng} / \mathrm{mL}$ or above is regarded as an indicator for prostate biopsy it misses between $20 \%$ and $40 \%$ of cancers $[17,18]$. It also falsely identifies indolent PCa causing $40 \%-50 \%$ of cases to be unnecessarily treated [19]. Lowering the PSA threshold has been suggested as an alternative to satisfy the current problems of the PSA test. However, when the PSA threshold is decreased there is an increased risk of identifying and unnecessarily treating indolent disease. In addition a PSA $>4 \mathrm{ng} / \mathrm{mL}$ can commonly be caused by $\mathrm{BPH}$, prostatitis [20] and rarely by other human malignancies [21].

A recent study [22] showed that patients diagnosed by PSA who underwent radical prostatectomy did not have a significant reduction in all-cause or PCa mortality as compared with those diagnosed by PSA, but who opted for active surveillance over a 12-year follow-up. Although this study presents some very interesting results, the fact that only $15 \%$ of men agreed to participate may have created statistical bias. Additionally, 12 years may be insufficient to assess PCa mortality. Furthermore, it suggested that radical prostatectomy might reduce mortality for men with a PSA $>10 \mathrm{ng} / \mathrm{mL}$ with higher-risk tumors. The risks and benefits of active surveillance need to be evaluated more stringently using a larger population and longer follow-up in order to establish a true opinion on the advantages of this approach.

Two large multi-center clinical trials $[23,24]$ has cast further doubt on the effectiveness of PSA screening. The European Randomized Study for Screening of Prostate Cancer (ERSPC) and the US-based Prostate, Lung, Colorectal and Ovarian (PLCO) Cancer Screening Trial focused on the mortality associated with PCa. The ERSPC trial concluded that in order to prevent one death from PCa, 1410 men needed to be screened and 48 treated. They also suggested that the only subjects that benefited from PSA screening were subjects in the 55-69 age group [5,25]. The PLCO trial was a smaller study (76,693 men from 10 centers in the United States) and concluded that $50 \%$ of men were over-diagnosed by PSA screening with no reduction in mortality over a 7-year period due to the slow growing nature of $\mathrm{PCa}$ [26]. It should be noted that this study included men who would not otherwise have been screened, and that follow-up at 7-years is insufficient to draw conclusions on mortality due to the slow growing nature of PCa.

Radical prostatectomy has a 10-year survival rate of approximately $77 \%$ [27]. The risk of death for modern radical prostatectomy is minimal but the procedure itself carries significant risk of urinary incontinence and erectile dysfunction in the short term, which is resolved over the long-term [28]. These are unacceptable risks if there is no benefit, as alluded to above. Furthermore, if a patient has an elevated PSA and abnormal prostate on DRE then biopsy, currently regarded as the only "certain" way of diagnosing PCa [29], is required. It follows that the unacceptably high false positive rates of the PSA test has led to unnecessary biopsy investigations. Biopsies themselves carry significant morbid side effects such as risk of subsequent erectile dysfunction, serious infections and urinary incontinence [30].

These issues have highlighted the need not only for a diagnostic biomarker but also for a prognostic marker for PCa. Early detection of symptomless PCa does not seem to save lives due to the very slow growing nature of PCa [31]. Those studies commonly cited as a rejection of PSA are in essence an assessment of the whole system of PCa diagnosis, including PSA, DRE and biopsy. Because of the low impact that early detection has had on saving lives, the new focus for a diagnostic test should be 
earlier detection of advanced disease, prediction of metastatic disease, distinguishing organ-confined versus extra-capsular invasion and recruitment to active surveillance and also more accurately inform clinical decision-making to avoid unnecessary treatments.

\section{Refinement of the PSA Test}

Developments have refined the PSA test to increase its diagnostic accuracy, including measurement of different molecular PSA forms and rate of PSA increase. Total PSA (tPSA) refers to the sum of free PSA (unbound) and bound PSA (complexed predominantly to $\alpha$-1-antichymotrypsin).

The rate of tPSA increase, as defined by total PSA velocity (tPSAV) [32], has received much interest both diagnostically and prognostically [33,34]. Prior to any diagnosis (including biopsy), or treatment, there appears little increased value of tPSAV above that of a single tPSA measure [35]. However, tPSAV has some diagnostic value with time as correlated in a study with repeat biopsies [36] and has value in informing decisions following diagnosis and treatment. Total PSA velocity is also useful if a patient has a history of repeat PSA measures where an increase above a patient's average value is most likely indicative of a prostate disorder.

The percentage free PSA test is approved for use in men that return a tPSA of between 4 and $10 \mathrm{ng} / \mathrm{mL}$ to help discriminate between the presence of PCa and BPH [37]. It is better than tPSA alone as a predictor for biopsy [38,39]. Whilst percentage free PSA enhances the diagnostic performance over total PSA, it still produces high false negatives [40] hence refining the tPSA still fails to fulfill the necessary requirements of an appropriate biomarker.

Recently Beckman Coulter (Coulter ACCESS ${ }^{\circledR}$ immunoassay system) introduced a measure of prostate health index (phi). This value is calculated from a combination of tPSA, free PSA and a measure of a truncated PSA isoform [-2]proPSA. A current systematic review and meta analysis demonstrates that \%[-2]proPSA has greater accuracy than tPSA or PPSA in detecting PCa detection in men that return a tPSA of between 2 and $10 \mathrm{ng} / \mathrm{mL}$ and that [-2]proPSA and its derivative phi might predict $\mathrm{PCa}$ aggressiveness [41].

\section{Biological Sampling and Tolerability}

As discussed, $\mathrm{PCa}$ is primarily diagnosed by pathological analysis of prostate needle biopsies. Biopsies are normally collected by ultrasound-directed transrectal sampling. In addition to being invasive, biopsies also carry other significant risks, such as subsequent infection. Two recent large cohort studies $[42,43]$ have demonstrated that there is significant hospitalization rates due to infection following biopsy, with a 3-4 fold increase above normal [44]. As highlighted by Loeb and colleagues [45], this is of concern with the increasing spectrum of antimicrobial resistant microorganisms worldwide. These increases in post-biopsy infection occurred despite the use of peri-procedural antimicrobial prophylaxis as recommended by the American Urological Association [46]. Prostate needle biopsy does not then meet the criteria required for an effective biomarker or diagnostic test. It is obviously invasive, has low tolerability and carries significant morbid risk with only samples limited to portions of the gland [46]. Hence, there is a concerted effort to identify and develop tests of highly specific biomarkers of PCa that are present in minimally invasive blood and urine samples (see Figure 1) which would be better tolerated by patients. 
Figure 1. Biomaterials currently available for the identification of prostate cancer biomarkers. Common biological specimens for PCa research include blood, urine, semen and prostate tissue. Each biological sample has associated advantages and disadvantages that may affect clinical validation of biomarkers and adoption for routine testing. Human plasma contains the largest amount of human proteins that could serve as potential markers for $\mathrm{PCa}$ diagnosis and prognosis. Urine has become a popular source for proteomic biomarker discovery and analysis due to its non-invasive nature. It contains a vast array of markers that could distinguish between healthy BPH and malignant PCa. Semen is a relatively non-invasive material for analyzing prostate biomarkers. Proteins directly from the prostate are easily accessed; however, there is a compositional variability among patients that poses an issue. Finally, prostate tissue, although a rich source of potential PCa biomarkers, is the most invasive of sampling sites. Abbreviations: CTCs, circulating tumor cells; miRNA, micro RNA; AMACR; alpha-methylacyl-CoA racemase.

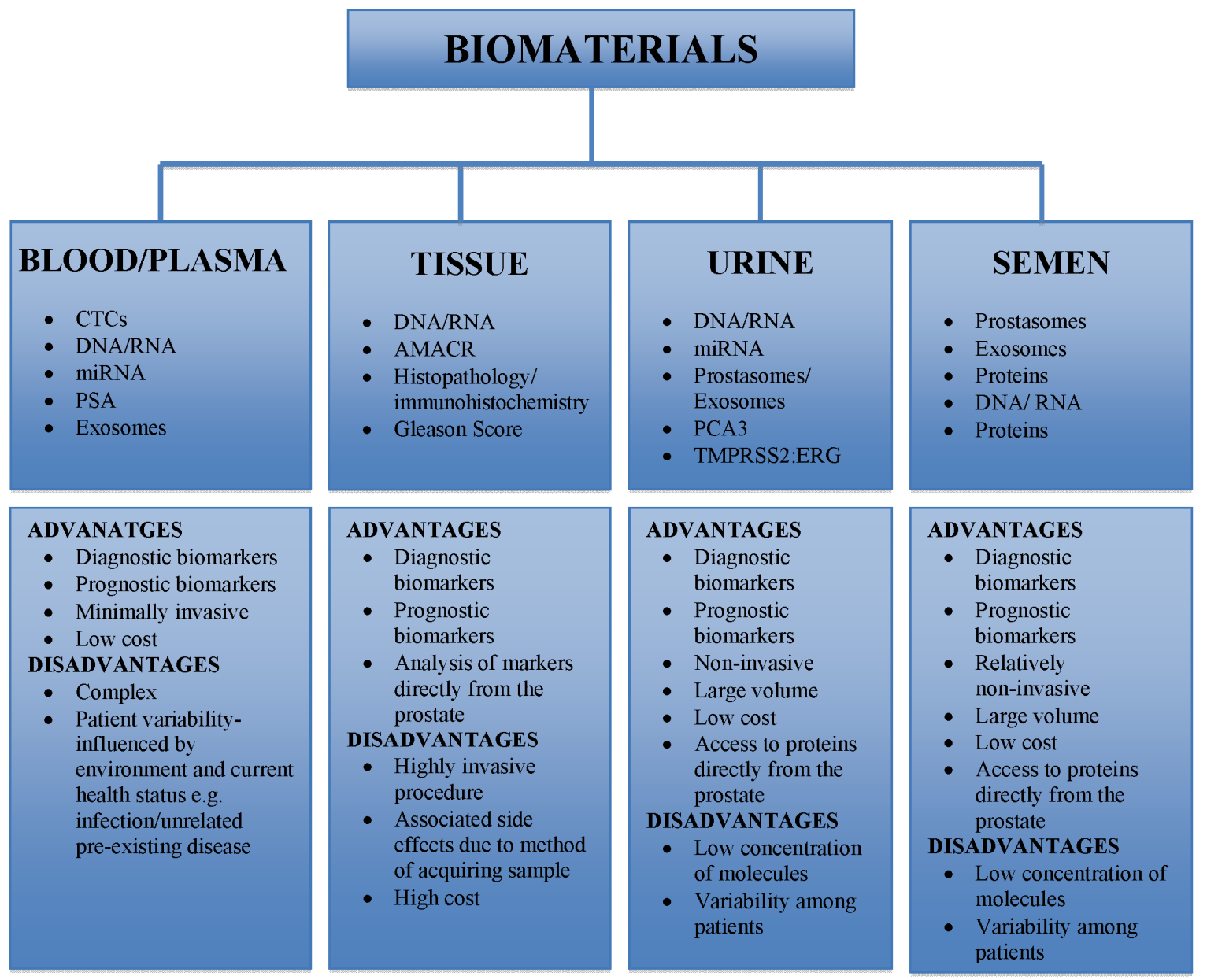

\section{Current and Emerging Biomarkers}

Proteomics and genomic technologies have significantly enhanced the discovery process of potential clinical biomarkers (Tables 1 and 2). Identifying biomarkers and understanding the key cancer-related pathways are essential for the development of new and improved diagnostic and predictive tools. The development of tumor-specific biomarkers has been a challenge and proteomics has contributed significantly to the identification of serum biomarkers for PCa [47]. 
Despite technological advances [48], serum proteomics still struggle to deal with the challenges presented by the wide range of protein concentrations, difficulty in finding low-abundance proteins due to the masking effects of high-abundance proteins [49], high levels of salts and other interfering compounds, extreme variations among individuals and lack of reproducibility which have diverted our attention to other possible biomarkers.

Table 1. Summary of proposed genetic biomarkers for prostate cancer diagnosis and prognosis.

\begin{tabular}{|c|c|c|c|}
\hline Marker & Product & Biological Function/ Relation to PCa & Reference \\
\hline$B 7-H 3(\mathrm{CD} 276)$ & Co-stimulatory molecule & $\begin{array}{l}\text { May act as antigen-specific inhibitor of } \\
\text { T-cell-mediated anti-tumoral immunity. Increased } \\
\text { expression worsens PCa prognosis. }\end{array}$ & {$[50-53]$} \\
\hline$K i-67$ & Nuclear protein & $\begin{array}{l}\text { Cell-cycle-proliferation marker. Possibly a prolific } \\
\text { predictive marker for men with low grade, low } \\
\text { volume PCa after radical prostatectomy. Associated } \\
\text { with metastasis and survival outcome. }\end{array}$ & {$[54,55]$} \\
\hline$E P C A$ & $\begin{array}{l}\text { Early Prostate Cancer } \\
\text { Antigen Nuclear matrix } \\
\text { protein }\end{array}$ & $\begin{array}{l}\text { PCa-associated nuclear structural protein measured in } \\
\text { serum. Expressed in prostate adenocarcinoma and } \\
\text { benign tissue; correlation with tumor progression and } \\
\text { poor prognosis. }\end{array}$ & {$[56-58]$} \\
\hline LAT1 (CD98) & Amino acid transporter & $\begin{array}{l}\text { Primary function is to transport essential amino acids. } \\
\text { Elevated LAT1 expression in PCa proposed as a novel } \\
\text { independent biomarker of high-grade malignancy. } \\
\text { LAT1 activity is considered essential for cancer cell } \\
\text { proliferation. }\end{array}$ & [59-61] \\
\hline$P C A 3$ & Non-coding RNA & $\begin{array}{l}\text { Produced in the prostate. Overexpressed compared to } \\
\text { non- malignant prostate tissue with a high specificity. }\end{array}$ & {$[2,62,63]$} \\
\hline$P S C A$ & $\begin{array}{l}\text { Prostate Stem Cell } \\
\text { Antigen, a membrane } \\
\text { glycoprotein }\end{array}$ & $\begin{array}{l}\text { Involved in the regulation of cell proliferation. } \\
\text { Up-regulated in the majority of PCas however, exact } \\
\text { biological function is unknown. Increased expression } \\
\text { is associated with Gleason score, seminal vesicle } \\
\text { invasion, and capsular invasion in PCa. }\end{array}$ & {$[55,64-66]$} \\
\hline $\begin{array}{l}\text { TMPRSS2-ERG } \\
\text { gene fusion }\end{array}$ & Transcription factor & $\begin{array}{l}\text { Secreted from prostate epithelial cells; expressed in } \\
\text { malignant prostate tissue. Independent marker of } \\
\text { disease progression and known marker of poor } \\
\text { prognosis. Detected in urine; small-scale studies } \\
\text { suggest high specificity and sensitivity. }\end{array}$ & {$[31,32,67-70]$} \\
\hline$B R C A 1 / B R C A 2$ & Tumor suppressor & $\begin{array}{l}\text { Both BRCA1 and BRCA2 are involved in maintaining } \\
\text { genome stability as members of the ATM/ATR CHK2 } \\
\text { DNA damage repair pathway. BRCA2 is associated } \\
\text { with aggressive tumors and poor survival outcome. } \\
\text { BRCA2 has prognostic ability however further } \\
\text { experimental data is needed for BRCA1. }\end{array}$ & {$[71-73]$} \\
\hline
\end{tabular}


Table 1. Cont.

\begin{tabular}{|c|c|c|c|}
\hline Marker & Product & Biological Function/ Relation to PCa & Reference \\
\hline PTEN & $\begin{array}{l}\text { Phosphatase and Tensin } \\
\text { homologue; protein } \\
\text { phosphatase }\end{array}$ & $\begin{array}{l}\text { Tumor suppressor involved in modulating the PI3- } \\
\text { K/AKT signaling pathway. PTEN inactivating } \\
\text { mutations/deletion occur in many tumors and result in } \\
\text { rapid cell growth and division. It is associated with } \\
\text { severe tumor stage; however, PTEN is not PCa } \\
\text { specific It is among one of the most frequent genetic } \\
\text { inactivation's present in PCa. }\end{array}$ & {$[74-76]$} \\
\hline PI3K & $\begin{array}{l}\text { Phosphoinositide-3- } \\
\text { kinase; Protein kinase. }\end{array}$ & $\begin{array}{l}\text { One of the most common genomic alterations in human } \\
\text { PCa contributing to cellular transformation and cancer } \\
\text { development. Possibly a key mechanism supporting } \\
\text { progression toward androgen-independent PCa. }\end{array}$ & {$[74,75]$} \\
\hline $\begin{array}{l}\text { PCa } 7 \text { gene panel } \\
C T A M, C X C R 3, \\
\text { FCRL3, KIAA1143, } \\
\text { KLF12, TMEM204, } \\
\text { SAMSN1 }\end{array}$ & $\begin{array}{l}\text { Uncharacterized, } \\
\text { Chemokine receptor } 3 \text {, } \\
\text { Fc receptor-like } 3 \text {, } \\
\text { uncharacterized, } \\
\text { Kruppel-like factor } 12, \\
\text { transmembrane protein } \\
\text { 204, and SH3 domain and } \\
\text { nuclear localization } \\
\text { signals } 1 \text { respectively }\end{array}$ & $\begin{array}{l}\text { A panel of } 7 \text { genes derived from blood mRNA could } \\
\text { distinguish between aggressive PCa and healthy } \\
\text { patients with a high sensitivity }(83 \%) \text { and specificity } \\
(80 \%) \text {. Genes involved in regulating the immune } \\
\text { response and gene transcription regulation in } \\
\text { oncogenesis. }\end{array}$ & {$[77]$} \\
\hline$M M E$ & $\begin{array}{l}\text { Membrane metallo- } \\
\text { endopeptidase/CD10 }\end{array}$ & $\begin{array}{l}\text { Inactivates several peptide hormones including } \\
\text { glucagon, abundant in the kidney. Candidate cancer } \\
\text { biomarker associated with PCa progression. A low } \\
\text { level of CD10 is a possible prognostic indicator for } \\
\text { biochemical relapse and early death as a result of } \\
\text { lymph node metastases. Additionally may aid in } \\
\text { personalized patient treatment/ management however } \\
\text { this marker needs to be further validated. }\end{array}$ & {$[78-80]$} \\
\hline PSGR & $\begin{array}{l}\text { Prostate Specific G } \\
\text { protein-coupled receptor } \\
\text { Protein-olfactory receptor }\end{array}$ & $\begin{array}{l}\text { Increased PSGR expression is associated with PCa } \\
\text { progression compared to normal tissue, possibly } \\
\text { involved in cell proliferation. Significant PSGR } \\
\text { alterations are observed in primary PCa cases } \\
\text { and overexpression is associated with higher } \\
\text { pathological stage. }\end{array}$ & {$[69,81]$} \\
\hline
\end{tabular}


Table 2. Summary of current and emerging protein biomarkers for the diagnosis and prognosis of prostate cancer.

\begin{tabular}{|c|c|c|c|}
\hline Protein Marker & Protein type & Biological Function/ Relation to PCa & Reference \\
\hline $\begin{array}{l}\text { Alpha-methylacyl- } \\
\text { CoA Racemase } \\
\text { (AMACR) }\end{array}$ & Racemase & $\begin{array}{l}\text { Metabolize fatty acids in the body. Over-expressed in } \mathrm{PCa} \\
\text { tissue; detected with a high sensitivity and specificity in blood } \\
\text { and urine. }\end{array}$ & {$[74-80]$} \\
\hline Endoglin (CD105) & $\begin{array}{l}\text { Trans membrane } \\
\text { glycoprotein }\end{array}$ & $\begin{array}{l}\text { Expressed by human vascular endothelial cells thought to play } \\
\text { a pivotal role in endothelial cell proliferation. Elevated in } \\
\text { prostatic fluid of men with large volume PCa. }\end{array}$ & {$[55,82-84]$} \\
\hline Engrailed 2; (EN-2) & $\begin{array}{l}\text { Transcription } \\
\text { factor }\end{array}$ & $\begin{array}{l}\text { Involved in early embryonic development and re-expressed by } \\
\text { PCa cells. EN-2 detection in urine as a test for diagnosing and } \\
\text { detecting PCa. Although further validation is required, it } \\
\text { appears it is more reliable than PSA and elevated expression is } \\
\text { associated with increased tumor stage. }\end{array}$ & {$[57-59]$} \\
\hline $\begin{array}{l}\text { Prostate-specific } \\
\text { membrane antigen } \\
\text { (PSMA) }\end{array}$ & $\begin{array}{l}\text { Type II integral } \\
\text { membrane } \\
\text { glycoprotein }\end{array}$ & $\begin{array}{l}\text { Overexpressed on prostate tumor cells and in the } \\
\text { neovasculature of most solid prostate tumors, but not in the } \\
\text { vasculature of normal tissues. May play an important role in the } \\
\text { progression of PCa. }\end{array}$ & {$[55,85-87]$} \\
\hline Caveolin-1 & $\begin{array}{l}\text { Integral } \\
\text { membrane } \\
\text { protein }\end{array}$ & $\begin{array}{l}\text { Mediates aspects of cholesterol and fatty acid metabolism. } \\
\text { Circulating levels of serum Caveolin-1 correlate with extent of } \\
\text { PCa. }\end{array}$ & {$[88,89]$} \\
\hline Interleukin-6 (IL-6) & Cytokine & $\begin{array}{l}\text { Involved in hematopoiesis and mediates B cell differentiation. } \\
\text { Clinical studies reveal increased serum IL-6 concentrations in } \\
\text { patients are associated with advanced PCa tumor stage. }\end{array}$ & {$[55,90]$} \\
\hline CD147 & $\begin{array}{l}\text { Membrane } \\
\text { glycoprotein }\end{array}$ & $\begin{array}{l}\text { Over-expressed in many human solid tumors. Involved in } \\
\text { tumor invasion and angiogenesis. Increased expression of } \\
\text { CD147 is associated with PCa progression and poor prognosis. } \\
\text { May serve as an independent predictor of biochemical } \\
\text { recurrence and development of PCa metastasis. }\end{array}$ & {$[91-93]$} \\
\hline $\begin{array}{l}\text { S100 Protein } \\
\text { Family }\end{array}$ & $\begin{array}{l}\text { Calcium- } \\
\text { binding-protein } \\
\text { family }\end{array}$ & $\begin{array}{l}\text { Expressed in various solid tumors. Detection may be useful for } \\
\text { diagnosis, monitoring and possible therapeutic targets. Involved } \\
\text { in protein phosphorylation, enzyme activity, calcium } \\
\text { homeostasis, and regulation of transcription factors, } \\
\text { macrophage activators and modulators of cell proliferation. } \\
\text { S100A2, S100A4, S100A8, S100A9 and S100A11 are } \\
\text { associated with PCa recurrence and advanced pathological } \\
\text { stage. }\end{array}$ & [94-98] \\
\hline $\begin{array}{l}\text { Annexin A3 } \\
\text { (ANXA3) }\end{array}$ & $\begin{array}{l}\text { Cell adhesion } \\
\text { protein }\end{array}$ & $\begin{array}{l}\text { A calcium and phospholipid binding protein, primarily found in } \\
\text { urine. Implicated in cell differentiation, migration and } \\
\text { immunomodulation. Increases the specificity and ability of PSA } \\
\text { to discriminate between PCa stages. }\end{array}$ & [99-103] \\
\hline TGF-Beta 1 & Cytokine & $\begin{array}{l}\text { Growth factor involved in the regulation of cellular } \\
\text { proliferation, immune response and differentiation. Increased } \\
\text { expression correlates with severe tumor grade, tumor invasion, } \\
\text { PCa metastasis and biochemical recurrence. TGF-Beta needs to } \\
\text { be validated before becoming a PCa biomarker. }\end{array}$ & {$[74,104-107]$} \\
\hline
\end{tabular}


Table 2. Cont.

\begin{tabular}{|c|c|c|c|}
\hline Protein Marker & Protein type & Biological Function/Relation to PCa & Reference \\
\hline $\begin{array}{l}\text { Human Kallikrein- } \\
2 \text { (KLK2) }\end{array}$ & Serine protease & $\begin{array}{l}\text { Serine protease that is highly expressed in prostate tissue and } \\
\text { involved regulating semen liquefaction by activating pro-KLK3 } \\
\text { to its active form (PSA), facilitating both tumorigenisis and } \\
\text { disease progression to the advanced stages of PCa. Studies have } \\
\text { shown a strong correlation with PCa- specific survival however } \\
\text { further studies with larger cohorts are needed to confirm these } \\
\text { observations. }\end{array}$ & {$[68,108,109]$} \\
\hline $\begin{array}{l}\text { Beta- } \\
\text { microseminoprotein } \\
(\text { MSMB) }\end{array}$ & $\begin{array}{l}\text { Immunoglobulin } \\
\text { binding factor }\end{array}$ & $\begin{array}{l}\text { Secreted by epithelial cells of the prostate as well as other } \\
\text { major organs. MSMB is a member of the immunoglobulin } \\
\text { binding family. Exact function of MSMB is unknown but may } \\
\text { have an autocrine (inhibin-like) role. The genetic variant } \\
\text { rs10993994 is associated with PCa risk however further } \\
\text { investigation is required to evaluate the predictive value of this } \\
\text { marker. }\end{array}$ & {$[110,111]$} \\
\hline
\end{tabular}

\subsection{Genetic Markers of Prostate Cancer}

Genomic analysis is widely used for studying disease biomarkers. Germ line genetic markers do not fluctuate over time and are available for assay at any age [112]. More than 40 PCa-susceptibility loci [113] were identified in the Genome-Wide Association Study, accounting for approximately 25\% of the familial risk of PCa. This was recently expanded by the International Practical Consortium to $70 \mathrm{PCa}$ susceptible loci accounting for approximately $30 \%$ of familial risk [114]. Therefore, the identification of key molecular elements in this heterogeneous cancer could lead to class-specific therapies.

Such genome wide analysis has the ability to stratify those most at risk. The report of Eeles et al. [114] has the ability to discriminate those top $1 \%$ of the population who have an almost 5 -fold greater risk of developing the disease. Such analysis does not however distinguish the likely aggressiveness of the ensuing disease. Such markers that have great promise in achieving this are those of $B R C A 1 / 2$. Several reports have identified an association with $B R C A 2$ mutations and an aggressive tumor with poor overall survival [71]. A recent large cohort study of both $B R C A 1$ and $B R C A 2$ confirms the prognostic ability of $B R C A 2$ mutations, but is inconclusive with regard to BRCA1 [72].

Prostate cancer antigen $3(P C A 3)$ is a biomarker currently commercially available as a diagnostic test marketed by Gen-Probe. This non-coding RNA is only expressed in the prostate, and can be detected in urine and prostatic fluid. Whilst this does not require the collection of blood, it is considered more invasive than blood-based tests, as it requires digital massage of the prostate prior to urine collection. It is over expressed in $95 \%$ of biopsies from PCa patients compared to healthy or BPH patients with a high specificity [115]. A PCA3 score of $>35$ units in urine has an average sensitivity of $66 \%$ and specificity of $76 \%$ for the diagnosis of PCa compared to serum PSA (specificity of $47 \%$ and $65 \%$ sensitivity) [116].

TMPRSS2:ERG is the most frequent gene fusion present in $\mathrm{PCa}$, accounting for approximately 90\% [117] of gene fusions. The TMPRSS2:ERG fusion has a greater than $90 \%$ specificity and $94 \%$ positive predictive value for PCa [118]. Although a clinical diagnostic test is still not available, this 
marker holds great promise. Combining PCA3 over-expression, TMPRSS2:ERG analysis and serum PSA testing is reported to improve screening effectiveness over PSA alone [119]. Unfortunately, current evidence does not support the ability of TMPRSS2:ERG analysis to be prognostic with equivocal findings regarding outcome [14,18,118]. For example, TMPRSS2:ERG the fusion has been found in patients with good prognosis [120] and with no association of incidence with Gleason score [121].

A recent study conducted by Liong et al. [77] proposed a new and simple way of distinguishing between PCa and control samples. This was carried out using a blood-based microarray analysis. Gene expression was further verified using qRT-PCR and together with statistical analysis, yielded a panel of seven genes (CTAM, CXCR3(CD183), FCRL3, KIAA1143, KLF12, TMEM204, SAMSN1) that could distinguish between aggressive $\mathrm{PCa}$ and healthy patients with a high sensitivity and specificity rate ( $83 \%$ and $80 \%$ respectively). The significant genes identified from blood derived mRNA have previously shown to be involved in the immune response, chemotaxis and gene transcription regulation in carcinogenesis [77,122-124].

\subsection{Circulating miRNAs in Prostate Cancer}

Micro RNAs (miRNAs) are naturally-occurring, small (22bp) non-coding RNAs [125,126], regulating the expression of more than $60 \%$ of protein-coding genes [127] and are therefore potential diagnostic indicators of tumor formation and metastasis [128,129]. PCa associated microRNAs in serum allow for minimally invasive diagnostic separation of samples from tumor burdened and healthy patients. miR-21, miR-125b, miR-221 and miR-222 (Table 1) are part of the oncogenic microRNA family that are up-regulated in human aggressive PCa [130]. miR-21 is over-expressed in PCa and other tumors acting as an oncogenic regulator leading to tumor growth [129] by silencing PTEN and other tumor suppressing genes [131]. The miR-200 family has recently generated interest in PCa research due to their lowered expression in PCa. A study of a Chinese population [123] identified a panel of five miRNA markers (let7-c, let7e, miR-30c, miR-622 and miR-1285) that differentiated PCa from benign and healthy control samples. Furthermore, combining the miRNA data with the PSA test improved PCa diagnosis. miRNA studies remain a challenge because of low nucleic acid recovery, their limited availability and data validation using independent methods [124].

\subsection{Protein-Based Biomarkers}

B7-H3, also known as CD276, is a co-stimulatory molecule that may act as an antigen-specific inhibitor of T-cell mediated anti-tumoral immunity in human cancers [13,50]. B7-H3 expression seems to worsen the prognosis of $\mathrm{PCa}$ malignancies, as it is observed in high pathological stage PCa [50,51]. The correlation between increased expression of this molecule with PCa stage may be useful in understanding the interaction of the immune system with prostate carcinoma and may better inform possible immune therapy intervention [13,52].

Immunohistological markers of $\mathrm{PCa}$ are also important in distinguishing between prostate tumor stages during biopsy analysis. Several molecules have been proposed, the most widely used marker being aplha-methylacyl-CoA Racemase (AMACR). It is expressed in $80 \%-100 \%$ of prostate adenocarcinomas [132] and detected in blood and urine with a high sensitivity and specificity [133-135]. AMACR also correlates with PCa metastasis and biochemical recurrence when 
levels are lowered [136] and its inhibitors have the potential to provide a novel treatment for castrate resistant prostate cancer (CRPC). Inter-assay variation of AMACR questions its use as a biomarker [70]. This is likely due to the presence of several variants that are better able to discriminate between normal as CaP tissues than total AMACR [137]. However, the biology must be well understood before its definite therapeutic potential can be realized [138]. Although this molecule seems to hold great promise as a diagnostic marker, it is not solely specific to PCa and thus is most useful as a prostate biopsy marker in a pathology setting [134,139].

Early prostate cancer antigen (EPCA) is a nuclear matrix protein that has received much attention culminating in the findings regarding EPCA-2 reported by Leman and colleagues being retracted. Work of others has demonstrated that it is expressed in both prostate adenocarcinoma and BPH [58]. More recent studies have shown a marked increase of EPCA in PCa [82,83] showing a correlation with tumor progression and poor post-operative prognosis [56,57]. Further investigation into this molecule is required in order to make a definite conclusion on its effectiveness as a PCa biomarker.

The multi gene calcium binding protein family, more commonly known as the S100 protein family are expressed in various solid tumors and detection may be useful for diagnosis, monitoring and possible therapeutic targets [96,98]. They are involved in protein phosphorylation, enzyme activity, calcium homeostasis, and regulation of transcription factors, macrophage activators and modulators of cell proliferation [94]. S100A2, S100A4, S100A8, S100A9 and S100A11 are specific proteins from this family associated with PCa recurrence and advanced pathological stage [64,95,98].

Human kallikrein 2 (KLK2), a possible serum marker for PCa may play a role in cancer progression and metastasis [140]. KLK2 is a secreted trypsin like protease, localized to prostatic epithelium that shares the exact $80 \%$ amino acid sequence with PSA and possibly activates and regulates PSA [141]. Studies have shown that when KLK2 and PSA are used in conjunction, PCa diagnosis is improved specifically with respect to extra-capsular extension and tumor volume [67,142]. The prognostic potential of KLK2 is still under investigation; however, it may serve as an additional biomarker to complement PSA as it also has the potential to predict biochemical recurrence in men with PSA levels less than $10 \mu \mathrm{g} / \mathrm{L}[16,143]$.

Recent development of a urine test based on the detection of Engrailed-2 has been utilized as a new tool for diagnosing PCa. Some studies have demonstrated it to be more reliable than PSA and DRE in detecting PCa. Morgan et al. [95] showed EN2 had a sensitivity of $66 \%$ and a specificity of $88 \%$ using PCa cell lines and PCa tissue, with DRE not required, proving to be a non-invasive method of diagnosis [144]. Patients with PCa generally have elevated levels of EN2 expression compared to normal prostate cells [145]. EN2 also has a strong correlation with tumor volume [146], despite it is still to be determined if EN2 can discriminate between aggressive and early stage tumors. The diagnostic and predictive value of this marker needs to be further evaluated.

Finally, an olfactory receptor known as the prostate-specific G-protein-coupled receptor (PSGR) has been shown to be specifically expressed in prostate epithelial cells [147]. Its expression is increased in PCa [81], suggesting that PSGR may play an important role in early PCa development and progression. PSGR activates major intracellular signaling cascades involved in cell survival causing an inhibition in PCa cell proliferation [82]. Their current role in tumor progression remains unknown, however there is promise that these olfactory receptors might form a new subset of potential biomarkers for the detection of PCa. 


\subsection{Immunological Biomarkers}

Cancers are known to activate the cellular immune system, including the mounting of an autoimmune response to antigens presented by the tumor [62]. This is due to, for example, overexpression, as in the case of AMACR [135]. Recent developments have targeted this autoimmune response in the development of multiplex arrays to detect autoimmune signatures that outperform PSA in detecting PCa with high specificity and sensitivity [148], and discriminate between PCa and BPH [149].

Cancer activation of the immune system also induces changes in surface proteins (antigens) of leukocytes that can be detected using an extensive array of cluster of differentiation (CD) antibodies $[150,151]$. As previously shown with melanoma and leukemia studies, observing the pattern of cell capture enables the detection of immune cell changes which can be quantified to effectively generate an immunophenotypical signature of the cancer [150-155].

Antibody microarray technology is built on the concept that leukocytes can be immobilized by the interaction of their surface $C D$ antigens with the anti-CD antibodies deposited as dots on a $2 \mathrm{D}$ surface [155] such as nitrocellulose. Anti-CD antibodies are associated with PCa, particularly CD44, CD147 and CD166 [156,157]. CD166 is significantly increased in serum from murine and human cases with CRPC and in metastatic PCa [156]. Similarly Hao et al. [157] showed that CD44 and CD147 are also associated with metastatic $\mathrm{PCa}$ that has the potential to alter the tumor microenvironment. Increased expression of CD147 is not only associated with increased risk of PSA failure and metastasis but also decreased overall survival in PCa [92]. However, the above CD markers are not PCa specific and are associated with other human diseases, diluting their diagnostic potential. In practice, better sensitivity and specificity (as determined by area under the relative operating characteristic (AUROC) curve) can be obtained by selecting a panel of CD antibodies [124] that could be specific to PCa when used in combination.

\subsection{Microparticles}

The incorporation of microparticles into diagnostic assays could enable more sensitive detection than current methods due to their origin and specificity. A recent review of membrane vesicles highlighted the importance of exosomes [158] which are released by most cancer cells [19]. These submicroscopic (30-100 nm diameter) particles [159] are secreted into the bloodstream, urine and semen [160], where they are important for cell-to-cell communication and hence are likely to play a significant role in tumorigenesis [161]. Exosomes may enable metastatic cells to avoid detection [162], evade apoptosis, and promote immuno-escape $[163,164]$. All exosomes express characteristic surface protein markers which enable their identification, such as CD9 [165], CD81 [166] and Alix [167]. However, they also contain specific intracellular proteins that can potentially be used to differentiate between different cancers.

Prostasomes are generated from both healthy and malignant prostate acinar cells and are secreted into seminal and prostatic fluids [168]. They range from 40 to $500 \mathrm{~nm}$ in diameter and are predominantly involved in the liquefaction of semen, enhancement of sperm mobility and possess immunosuppressive, antioxidant and antibacterial properties [169]. PCa patients have increased numbers of prostasomes in their semen compared to men without disease and elevated levels of these vesicles correlate with an increased Gleason score [170]. 
Prostasomes specifically express CD46, CD55 and CD59 [171] which play significant roles in the immune system [170]. CD59 levels are greater in prostasomes isolated from metastatic prostate cells compared to non-PCa [172]. Material can be transferred from prostasomes to cancer cells where they prevent complement-mediated cell lysis, thereby allowing the $\mathrm{PCa}$ cells to survive the host complement system [173,174]. Exosomes and prostasomes are derived from PCa cells and therefore carry intracellular molecules (see Table 3) that may be PCa specific, which can contribute to the discovery of novel PCa markers [132].

Table 3. Summary of diagnostic and prognostic potential of circulating tumor cells (CTCs) prostasomes and exosomes in prostate cancer.

\begin{tabular}{|c|c|c|}
\hline Category & Summary & Reference \\
\hline $\begin{array}{l}\text { Circulating } \\
\text { tumor cells } \\
\text { (CTCs) }\end{array}$ & $\begin{array}{l}\text { CTCs detected in blood have been proposed for monitoring disease progression and } \\
\text { evaluating effectiveness of cancer therapy. They carry important information specific } \\
\text { to tumor type and stage however low CTC detection in blood proves to be a technical } \\
\text { hurdle. Prostate cancer derived CTCs possess those same mutations present in the } \\
\text { primary tumor ( } P T E N, T M P R S S 2, A M A C R \text { ), which may provide a more readily } \\
\text { accessible source of important prognostic information for patients. To date the high } \\
\text { cost associated with their analysis and controversial clinical relevance has prevented } \\
\text { their use in clinical setting. }\end{array}$ & {$[175,176]$} \\
\hline Prostasomes & $\begin{array}{l}\text { Prostasomes are sub-micrometer membranous vesicles, generated from normal and } \\
\text { malignant prostate cells. They are found in blood, urine, semen and prostatic fluid. } \\
\text { An increased abundance of prostasomes have been associated with PCa and elevated } \\
\text { Gleason score. They carry specific markers (CD46, CD55, CD59) that play a role } \\
\text { in the immune system. Additionally, they carry specific molecules, both intracellular } \\
\text { and extracellular, that may be specific to PCa and aid in the discovery of new } \\
\text { PCa biomarkers. }\end{array}$ & {$[170,173,174]$} \\
\hline Exosomes & $\begin{array}{l}\text { Exosomes are cell-derived vesicles isolated from blood, urine and cell lines. Exosomes } \\
\text { are released from most cancer types and possess immunosuppressive properties thought } \\
\text { to play a significant role in oncogenesis. All exosomes express specific markers (CD9, } \\
\text { Alix, CD81) that enable easier detection and isolation. In addition to these common } \\
\text { markers, exosomes express specific markers unique to PCa and the cells from which } \\
\text { they were derived. They can potentially characterize different stages of PCa and hold } \\
\text { prognostic potential. }\end{array}$ & {$[159,161]$} \\
\hline
\end{tabular}

\subsection{Circulating Tumor Cells}

Circulating tumor cells (CTCs) may be a useful approach to monitoring disease progression, and measuring treatment effects in various malignancies. Patients with a CTC count of more than $5 \mathrm{CTCs} / 7.5 \mathrm{~mL}$ blood have a significantly reduced overall survival compared to patients with less than 5 CTCs/7.5 mL blood [30,175]. However, current studies are limited by the low CTC detection rate [123]. To date no significant difference has been reported between CTCs from patients with biopsy-proven localized disease and biopsy-negative disease [139]. PCa CTCs are reported to reflect those mutations present in the primary tumor e.g., TMPRSS2-ERG fusions, androgen receptor mutations, and PTEN deletion which, together with PSA, AMACR and androgen receptors, can predict the response to treatment $[176,177]$. 
The number of CTCs present in whole blood might allow for determination of cancer burden, and provide a more readily accessible source of molecular information of the primary tumor. Despite their promise and proposed function, CTC detection remains a major technical challenge [178] and their clinical relevance remains controversial. Nevertheless, this research promises to understand the biology of specific subclasses of PCa in particular, castrate resistant prostate cancer using a minimally invasive technique. CTCs have the potential to reform our understanding of cancer and enhance individual treatment (Table 3). However, the labor-intensive nature of isolating CTCs, high cost and the extremely low numbers in blood is a technical hurdle, especially in the early stages of PCa.

\section{Conclusions}

With the well-described drawbacks of the PSA test, there is a concerted effort to develop replacement-screening tools for PCa. The PSA test is currently the best biomarker for PCa recurrence and it has undoubtedly been partly responsible for the increased awareness of PCa. However, no study to date has proven that screening with PSA reduces PCa mortality. It will be a challenge to replace PSA entirely due to its minimally invasive nature and low cost but there is a pressing need to complement PSA with biomarkers that can increase the specificity and sensitivity of a screen. A panel of diagnostic and prognostic biomarkers that will work in conjunction with PSA will be ideal.

Detecting multiple analytes at the same time in one sample is ideal. Different multiplex platforms are able to achieve this, such as ELISA, mass spectrometry and antibody arrays, although each method has its advantages and disadvantages. In a typical double antibody ELISA, two markers - a primary and secondary antibody - are used to increase the accuracy, specificity and detection of the antigen of interest. However, the performance of the ELISA is dependent on the quality of the antibody and the methodology employed by the user. ELISAs also lack sensitivity when using the traditional method and are relatively time consuming. Cross reactivity of antibodies is yet another drawback of this method. The possibility of an antibody binding to more than one antigen, yielding a false-positive result is a common problem. Furthermore, the analysis of only a single antigen at a time is not ideal due to the heterogeneity of the PCa. It is highly unlikely that only one marker will sufficiently screen and accurately diagnose all patients.

The analysis of a panel of multiple biomarkers may better reflect the disease state of an individual and such multiplex assays are the focus for many groups [63,179]. An antibody array is one method that has been proposed to analyze multiple markers simultaneously from a small biological sample. This method is relatively easy to use and efficient; however, the accuracy and reproducibility of this assay must be investigated. Additionally, this platform shares some of the same disadvantages as the ELISA. Inter- and intra-laboratory variability is an issue yields different results among clinics. These issues must be addressed before it can be used for the diagnosis of PCa patients.

As with antibody arrays, mass spectrometry is able to concurrently quantify multiple protein analytes at a time from a single sample. Recent advances in mass spectrometry has acquired much attention and led to the discovery of candidate protein-based markers of disease. Generally, mass spectrometry requires small sample size, fast and easily differentiates isotypes. However, its use in a clinical setting is problematic due to time-consuming data analysis and high cost to run individual samples. Quantification by mass spectroscopy can also be an issue. Unless further advances are made 
where these problems are avoided, mass spectrometry is best used at a research level to identify possible markers that may form the basis of a diagnostic test for PCa.

In addition to technological issues, there are also pre-analytical methods that may prevent the discovery, replication and validation of biomarkers. Variation among sample collection, handling and storage procedures, control samples and the experience of individual operators are all elements that contribute to varying outcomes of the "same" experiment, leading to the failure of candidate biomarkers not being validated for use in clinical practice. Standard methodologies and guidelines must be developed where identical controls and statistical models are used to analyze different data sets. Finally, inconsistent patient numbers among studies and sample collection bias has contributed to the lack of success when it comes to validating potential biomarkers. Many studies limit sample collection to a particular clinic or geographical location. Blinded sample collection from a number of clinics and a statistical power analysis can contribute to further verifying the diagnostic and prognostic potential of particular candidate biomarkers. The characteristics required for a suitable replacement for PSA include high sensitivity and specificity, that a marker is quantifiable and provide rapid results at low cost using a sampling methodology that is well tolerated by patients. Any replacement test should be capable of monitoring disease progression and able to distinguish between men with clinically significant PCa from those with clinically insignificant PCa. Furthermore, in early stage disease not only should a test detect PCa but also inform an appropriate individualized treatment strategy from active surveillance to an aggressive approach of surgery or radiation/chemotherapy. Tissue samples as a biomaterial to assess biomarkers is far from ideal due to the significant sampling error associated with this technique and its highly invasive approach (Figure 1). The next generation of PCa biomarkers should ideally come from minimally invasive procedures, such as urine or blood, and a robust and reproducible methodology (Figure 1). Urine and blood collection is already part of standard pathology practice and is well tolerated by patients.

Currently, no single test can achieve the above goals and we predict that one single biomarker will not be able to fulfill the above requirements for the next PCa screening tool. Due to the heterogeneity of the disease, no one biomarker will be diagnostic and prognostic for every patient. On this basis, we surmise that the next "PSA test" will most likely be an assay employing multiple biomarkers assayed in combination using protein and gene microarrays, containing markers that are differentially expressed in PCa.

\section{Conflict of Interest}

The authors declare no conflict of interest.

\section{References}

1. Thorne, H.; Willems, A.J.; Niedermayr, E.; Hoh, I.M.; Li, J.; Clouston, D.; Mitchell, G.; Fox, S.; Hopper, J.L.; Bolton, D. Decreased prostate cancer-specific survival of men with BRCA2 mutations from multiple breast cancer families. Cancer Prev. Res. (Phila) 2011, 4, 1002-1010.

2. Prostate Cancer Foundation Australia. What is Prostate Cancer. Available online: http://www. prostate.org.au/articleLive/pages/What-is-Prostate-Cancer.html (accessed on 18 March 2013). 
3. Bangma, C.H.; Roemeling, S.; Schroder, F.H. Overdiagnosis and overtreatment of early detected prostate cancer. World J. Urol. 2007, 25, 3-9.

4. Assinder, S.J.; Nicholson, H. Prostate Disease: Prostate hyperplasia and prostate cancer and prostatitis. In Pathophysiology and Treatment of Male Sexual and Reproductive Dysfunction; Kandeel, E.F., Ed.; Marcel Dekker Inc.: New York, NY, USA, 2007; pp. 423-439.

5. Schroder, F.H.; Hugosson, J.; Roobol, M.J.; Tammela, T.L.; Ciatto, S.; Nelen, V.; Kwiatkowski, M.; Lujan, M.; Lilja, H.; Zappa, M.; et al. Screening and prostate-cancer mortality in a randomized European study. N. Engl. J. Med. 2009, 360, 1320-1328.

6. Moyer, V.A. Screening for prostate cancer: U.S. preventive services task force recommendation statement. Ann. Intern. Med. 2012, 157, 120-134.

7. Schroder, F.H. Stratifying risk-The U.S. preventive services task force and prostate-cancer screening. N. Engl. J. Med. 2011, 365, 1953-1955.

8. National Cancer Institute. NCI Dictionary of Cancer Terms. Available online: http://www.cancer. gov/dictionary?cdrid=45618 (accessed on 20 May 2013).

9. Gutman, A.B.; Gutman, E.B. An "Acid" phosphatase occurring in the serum of patients with metastasizing carcinoma of the prostate gland. J. Clin. Invest. 1938, 17, 473-478.

10. Hernandez, J.; Thompson, I.M. Prostate-specific antigen: A review of the validation of the most commonly used cancer biomarker. Cancer 2004, 101, 894-904.

11. Hara, M.; Koyanagi, Y.; Inoue, T.; Fukuyama, T. Some physico-chemical characteristics of "-seminoprotein", an antigenic component specific for human seminal plasma. Forensic immunological study of body fluids and secretion. VII. NIhon Hogaku Zasshi 1971, 25, 322-324.

12. Pinsky, P.F.; Kramer, B.S.; Crawford, E.D.; Grubb, R.L.; Urban, D.A.; Andriole, G.L.; Chia, D.; Levin, D.L.; Gohagan, J.K. Prostate volume and prostate-specific antigen levels in men enrolled in a large screening trial. Urology 2006, 68, 352-356.

13. Liu, Y.; Hegde, P.; Zhang, F.; Hampton, G.; Jia, S. Prostate cancer-A biomarker perspective. Front. endocrinol. 2012, 3, 72-79.

14. Hessels, D.; Schalken, J.A. Urinary biomarkers for prostate cancer: A review. Asian J. Androl. 2013, doi:10.1038/aja.2013.6.

15. Cross, D.S.; Ritter, M.; Reding, D.J. Historical prostate cancer screening and treatment outcomes from a single institution. Clin. Med. Res. 2012, 10, 97-105.

16. Sardana, G.; Jung, K.; Stephan, C.; Diamandis, E.P. Proteomic analysis of conditioned media from the PC3, LNCaP, and 22Rv1 prostate cancer cell lines: Discovery and validation of candidate prostate cancer biomarkers. J. Proteome Res. 2008, 7, 3329-3338.

17. Mistry, K.; Cable, G. Meta-analysis of prostate-specific antigen and digital rectal examination as screening tests for prostate carcinoma. J. Am. Board Fam. Pract. 2003, 16, 95-101.

18. Schroder, F.H.; van der Cruijsen-Koeter, I.; de Koning, H.J.; Vis, A.N.; Hoedemaeker, R.F.; Kranse, R. Prostate cancer detection at low prostate specific antigen. J. Urol. 2000, 163, 806-812.

19. Lin, M.W.; Ho, J.W.; Harrison, L.C.; Dos Remedios, C.G.; Adelstein, S. An antibody-based leukocyte-capture microarray for the diagnosis of systemic lupus erythematosus. PLoS One 2013, doi:10.1371/journal.pone.0058199.

20. Haythorn, M.R.; Ablin, R.J. Prostate-specific antigen testing across the spectrum of prostate cancer. Biomark. Med. 2011, 5, 515-526. 
21. Bodey, B.; Bodey, B., Jr.; Kaiser, H.E. Immunocytochemical detection of prostate specific antigen expression in human primary and metastatic melanomas. Anticancer Res. 1997, 17, 2343-2346.

22. Wilt, T.J.; Brawer, M.K.; Jones, K.M.; Barry, M.J.; Aronson, W.J.; Fox, S.; Gingrich, J.R.; Wei, J.T.; Gilhooly, P.; Grob, B.M.; et al. Radical prostatectomy versus observation for localized prostate cancer. N. Engl. J. Med. 2012, 367, 203-213.

23. Andriole, G.L.; Crawford, E.D.; Grubb, R.L., III; Buys, S.S.; Chia, D.; Church, T.R.; Fouad, M.N.; Isaacs, C.; Kvale, P.A.; Reding, D.J.; et al. Prostate cancer screening in the randomized prostate, lung, colorectal, and ovarian cancer screening trial: Mortality results after 13 years of follow-up. J. Natl. Cancer Inst. 2012, 104, 125-132.

24. Roobol, M.J.; Zhu, X.; Schroder, F.H.; van Leenders, G.J.; van Schaik, R.H.; Bangma, C.H.; Steyerberg, E.W. A calculator for prostate cancer risk 4 years after an initially negative screen: Findings from ERSPC rotterdam. Eur. Urol. 2012, 4, 627-633.

25. Eckersberger, E.; Finkelstein, J.; Sadri, H.; Margreiter, M.; Taneja, S.S.; Lepor, H.; Djavan, B. Screening for prostate cancer: A review of the ERSPC and PLCO trials. Rev. Urol. 2009, 11, 127-133.

26. Gomella, L.G.; Liu, X.S.; Trabulsi, E.J.; Kelly, W.K.; Myers, R.; Showalter, T.; Dicker, A.; Wender, R. Screening for prostate cancer: The current evidence and guidelines controversy. Can. J. Urol. 2011, 18, 5875-5883.

27. Pierorazio, P.M.; Guzzo, T.J.; Han, M.; Bivalacqua, T.J.; Epstein, J.I.; Schaeffer, E.M.; Schoenberg, M.; Walsh, P.C.; Partin, A.W. Long-term survival after radical prostatectomy for men with high Gleason sum in pathologic specimen. Urology 2010, 76, 715-721.

28. Resnick, M.J.; Koyama, T.; Fan, K.H.; Albertsen, P.C.; Goodman, M.; Hamilton, A.S.; Hoffman, R.M.; Potosky, A.L.; Stanford, J.L.; Stroup, A.M.; et al. Long-term functional outcomes after treatment for localized prostate cancer. N. Engl. J. Med. 2013, 368, 436-445.

29. Peyromaure, M.; Ravery, V.; Messas, A.; Toublanc, M.; Boccon-Gibod, L.; Boccon-Gibod, L. Pain and morbidity of an extensive prostate 10-biopsy protocol: A prospective study in 289 patients. J. Urol. 2002, 167, 218-221.

30. Seftel, A.D. Prostate cancer diagnosis is associated with an increased risk of erectile dysfunction after prostate biopsy. J. Urol. 2012, 188, 2317-2318.

31. Sardana, G.; Diamandis, E.P. Biomarkers for the diagnosis of new and recurrent prostate cancer. Biomark. Med. 2012, 6, 587-596.

32. Connolly, D.; Black, A.; Murray, L.J.; Napolitano, G.; Gavin, A.; Keane, P.F. Methods of calculating prostate-specific antigen velocity. Eur. Urol. 2007, 52, 1044-1050.

33. Shariat, S.F.; Semjonow, A.; Lilja, H.; Savage, C.; Vickers, A.J.; Bjartell, A. Tumor markers in prostate cancer I: Blood-based markers. Acta Oncol. 2011, 50, 61-75.

34. Zheng, X.Y.; Zhang, P.; Xie, L.P.; You, Q.H.; Cai, B.S.; Qin, J. Prostate-specific antigen velocity (PSAV) and PSAV per initial volume (PSAVD) for early detection of prostate cancer in Chinese men. Asian Pac. J. Cancer Prev. 2012, 13, 5529-5533.

35. Shariat, S.F.; Scardino, P.T.; Lilja, H. Screening for prostate cancer: An update. Can. J. Urol. 2008, 15, 4363-4374. 
36. Auprich, M.; Augustin, H.; Budaus, L.; Kluth, L.; Mannweiler, S.; Shariat, S.F.; Fisch, M.; Graefen, M.; Pummer, K.; Chun, F.K. A comparative performance analysis of total prostate-specific antigen, percentage free prostate-specific antigen, prostate-specific antigen velocity and urinary prostate cancer gene 3 in the first, second and third repeat prostate biopsy. BJU Int. 2012, 109, 1627-1635.

37. Catalona, W.J.; Partin, A.W.; Slawin, K.M.; Brawer, M.K.; Flanigan, R.C.; Patel, A.; Richie, J.P.; deKernion, J.B.; Walsh, P.C.; Scardino, P.T.; et al. Use of the percentage of free prostate-specific antigen to enhance differentiation of prostate cancer from benign prostatic disease: A prospective multicenter clinical trial. J. Am. Med. Assoc. 1998, 279, 1542-1547.

38. Roddam, A.W.; Duffy, M.J.; Hamdy, F.C.; Ward, A.M.; Patnick, J.; Price, C.P.; Rimmer, J.; Sturgeon, C.; White, P.; Allen, N.E. Use of prostate-specific antigen (PSA) isoforms for the detection of prostate cancer in men with a PSA level of 2-10 ng/mL: Systematic review and meta-analysis. Eur. Urol. 2005, 48, 386-399.

39. Chun, F.K.; Suardi, N.; Capitanio, U.; Jeldres, C.; Ahyai, S.; Graefen, M.; Haese, A.; Steuber, T.; Erbersdobler, A.; Montorsi, F.; et al. Assessment of pathological prostate cancer characteristics in men with favorable biopsy features on predominantly sextant biopsy. Eur. Urol. 2009, 55, 617-628.

40. Capitanio, U.; Ahyai, S.; Graefen, M.; Jeldres, C.; Shariat, S.F.; Erbersdobler, A.; Schlomm, T.; Haese, A.; Steuber, T.; Heinzer, H.; et al. Assessment of biochemical recurrence rate in patients with pathologically confirmed insignificant prostate cancer. Urology 2008, 72, 1208-1211.

41. Filella, X.; Gimenez, N. Evaluation of [-2]proPSA and Prostate Health Index (phi) for the detection of prostate cancer: A systematic review and meta-analysis. Clin. Chem. Lab. Med. 2013, 51, 729-739.

42. Nam, R.K.; Saskin, R.; Lee, Y.; Liu, Y.; Law, C.; Klotz, L.H.; Loblaw, D.A.; Trachtenberg, J.; Stanimirovic, A.; Simor, A.E.; et al. Increasing hospital admission rates for urological complications after transrectal ultrasound guided prostate biopsy. J. Urol. 2013, 189, S12-S18.

43. Loeb, S.; Carter, H.B.; Catalona, W.J.; Moul, J.W.; Schroder, F.H. Baseline prostate-specific antigen testing at a young age. Eur. Urol. 2012, 61, 1-7.

44. Nam, R.K.; Saskin, R.; Lee, Y.; Liu, Y.; Law, C.; Klotz, L.H.; Loblaw, D.A.; Trachtenberg, J.; Stanimirovic, A.; Simor, A.E.; et al. Increasing hospital admission rates for urological complications after transrectal ultrasound guided prostate biopsy. J. Urol. 2010, 183, 963-968.

45. Loeb, S.; van den Heuvel, S.; Zhu, X.; Bangma, C.H.; Schroder, F.H.; Roobol, M.J. Infectious complications and hospital admissions after prostate biopsy in a European randomized trial. Eur. Urol. 2012, 61, 1110-1114.

46. Loeb, S. Prostate biopsy: A risk-benefit analysis. J. Urol. 2010, 183, 852-853.

47. Goo, Y.A.; Goodlett, D.R. Advances in proteomic prostate cancer biomarker discovery. J. Proteomics 2010, 73, 1839-1850.

48. Nedelkov, D. Mass spectrometry-based protein assays for in vitro diagnostic testing. Expert Rev. Mol. Diagn. 2012, 12, 235-239.

49. Wu, C.C.; Yates, J.R., III. The application of mass spectrometry to membrane proteomics. Nat. Biotechnol. 2003, 21, 262-267. 
50. Liu, Y.; Vlatkovic, L.; Saeter, T.; Servoll, E.; Waaler, G.; Nesland, J.M.; Giercksky, K.E.; Axcrona, K. Is the clinical malignant phenotype of prostate cancer a result of a highly proliferative immune-evasive B7-H3-expressing cell population? Int. J. Urol. 2012, 19, 749-756.

51. Mahnke, K.; Ring, S.; Johnson, T.S.; Schallenberg, S.; Schonfeld, K.; Storn, V.; Bedke, T.; Enk, A.H. Induction of immunosuppressive functions of dendritic cells in vivo by CD4+CD25+ regulatory T cells: Role of B7-H3 expression and antigen presentation. Eur. J. Immunol. 2007, 37, 2117-2126.

52. Roth, T.J.; Sheinin, Y.; Lohse, C.M.; Kuntz, S.M.; Frigola, X.; Inman, B.A.; Krambeck, A.E.; McKenney, M.E.; Karnes, R.J.; Blute, M.L.; et al. B7-H3 ligand expression by prostate cancer: A novel marker of prognosis and potential target for therapy. Cancer Res. 2007, 67, 7893-7900.

53. Zang, X.; Thompson, R.H.; Al-Ahmadie, H.A.; Serio, A.M.; Reuter, V.E.; Eastham, J.A.; Scardino, P.T.; Sharma, P.; Allison, J.P. B7-H3 and B7x are highly expressed in human prostate cancer and associated with disease spread and poor outcome. Proc. Natl. Acad. Sci. USA 2007, 104, 19458-19463.

54. Gerdes, J.; Lemke, H.; Baisch, H.; Wacker, H.H.; Schwab, U.; Stein, H. Cell cycle analysis of a cell proliferation-associated human nuclear antigen defined by the monoclonal antibody Ki-67. J. Immunol. 1984, 133, 1710-1715.

55. Madu, C.O.; Lu, Y. Novel diagnostic biomarkers for prostate cancer. J. Cancer 2010, 1, 150-177.

56. Zhao, Z.; Zeng, G.; Zhong, W. Serum early prostate cancer antigen (EPCA) as a significant predictor of incidental prostate cancer in patients undergoing transurethral resection of the prostate for benign prostatic hyperplasia. Prostate 2010, 70, 1788-1798.

57. Zhao, Z.; Ma, W.; Zeng, G.; Qi, D.; Ou, L.; Liang, Y. Preoperative serum levels of early prostate cancer antigen (EPCA) predict prostate cancer progression in patients undergoing radical prostatectomy. Prostate 2012, 72, 270-279.

58. Uetsuki, H.; Tsunemori, H.; Taoka, R.; Haba, R.; Ishikawa, M.; Kakehi, Y. Expression of a novel biomarker, EPCA, in adenocarcinomas and precancerous lesions in the prostate. J. Urol. 2005, $174,514-518$.

59. Sakata, T.; Ferdous, G.; Tsuruta, T.; Satoh, T.; Baba, S.; Muto, T.; Ueno, A.; Kanai, Y.; Endou, H.; Okayasu, I. L-type amino-acid transporter 1 as a novel biomarker for high-grade malignancy in prostate cancer. Pathol. Int. 2009, 59, 7-18.

60. Kanai, Y.; Segawa, H.; Miyamoto, K.; Uchino, H.; Takeda, E.; Endou, H. Expression cloning and characterization of a transporter for large neutral amino acids activated by the heavy chain of 4F2 antigen (CD98). J. Biol. Chem. 1998, 273, 23629-23632.

61. Kanai, Y.; Endou, H. Heterodimeric amino acid transporters: Molecular biology and pathological and pharmacological relevance. Curr. Drug Metabol. 2001, 2, 339-354.

62. Grivennikov, S.I.; Greten, F.R.; Karin, M. Immunity, inflammation, and cancer. Cell 2010, 140, 883-899.

63. Xie, C.; Kim, H.J.; Haw, J.G.; Kalbasi, A.; Gardner, B.K.; Li, G.; Rao, J.; Chia, D.; Liong, M.; Punzalan, R.R.; et al. A novel multiplex assay combining autoantibodies plus PSA has potential implications for classification of prostate cancer from non-malignant cases. J. Transl. Med. 2011, 9, 43 . 
64. Ramirez, M.L.; Nelson, E.C.; Evans, C.P. Beyond prostate-specific antigen: Alternate serum markers. Prostate Cancer Prostatic Dis. 2008, 11, 216-229.

65. Beckett, M.L.; Cazares, L.H.; Vlahou, A.; Schellhammer, P.F.; Wright, G.L., Jr. Prostate-specific membrane antigen levels in sera from healthy men and patients with benign prostate hyperplasia or prostate cancer. Clin. Cancer Res. 1999, 5, 4034-4040.

66. Reiter, R.E.; Gu, Z.; Watabe, T.; Thomas, G.; Szigeti, K.; Davis, E.; Wahl, M.; Nisitani, S.; Yamashiro, J.; Le Beau, M.M.; et al. Prostate stem cell antigen: A cell surface marker overexpressed in prostate cancer. Proc. Natl. Acad. Sci. USA 1998, 95, 1735-1740.

67. Haese, A.; Graefen, M.; Steuber, T.; Becker, C.; Noldus, J.; Erbersdobler, A.; Huland, E.; Huland, H.; Lilja, H. Total and Gleason grade 4/5 cancer volumes are major contributors of human kallikrein 2, whereas free prostate specific antigen is largely contributed by benign gland volume in serum from patients with prostate cancer or benign prostatic biopsies. J. Urol. 2003, 170, 2269-2273.

68. Kohli, M.; Rothberg, P.G.; Feng, C.; Messing, E.; Joseph, J.; Rao, S.S.; Hendershot, A.; Sahsrabudhe, D. Exploratory study of a KLK2 polymorphism as a prognostic marker in prostate cancer. Cancer Biomark. 2010, 7, 101-108.

69. Xia, C.; Ma, W.; Wang, F.; Hua, S.; Liu, M. Identification of a prostate-specific G-protein coupled receptor in prostate cancer. Oncogene 2001, 20, 5903-5907.

70. Adley, B.P.; Yang, X.J. Application of alpha-methylacyl coenzyme A racemase immunohistochemistry in the diagnosis of prostate cancer: A review. Anal. Quant. Cytol. Histol. 2006, 28, 1-13.

71. Edwards, S.M.; Evans, D.G.; Hope, Q.; Norman, A.R.; Barbachano, Y.; Bullock, S.; Kote-Jarai, Z.; Meitz, J.; Falconer, A.; Osin, P.; et al. Prostate cancer in BRCA2 germline mutation carriers is associated with poorer prognosis. Br. J. Cancer 2010, 103, 918-924.

72. Castro, E.; Goh, C.; Olmos, D.; Saunders, E.; Leongamornlert, D.; Tymrakiewicz, M.; Mahmud, N.; Dadaev, T.; Govindasami, K.; Guy, M.; et al. Germline BRCA mutations are associated with higher risk of nodal involvement, distant metastasis, and poor survival outcomes in prostate cancer. J. Clin. Oncol. 2013, doi:10.1200/JCO.2012.43.1882.

73. Vesprini, D.; Liu, S.; Nam, R. Predicting high risk disease using serum and DNA biomarkers. Curr. Opin. Urol. 2013, 23, 252-260.

74. Qin, J.; Wu, S.P.; Creighton, C.J.; Dai, F.; Xie, X.; Cheng, C.M.; Frolov, A.; Ayala, G.; Lin, X.; Feng, X.H.; et al. COUP-TFII inhibits TGF-beta-induced growth barrier to promote prostate tumorigenesis. Nature 2013, 493, 236-240.

75. Schutzman, J.L.; Martin, G.R. Sprouty genes function in suppression of prostate tumorigenesis. Proc. Natl. Acad. Sci. USA 2012, 109, 20023-20028.

76. Sowalsky, A.G.; Ye, H.; Bubley, G.J.; Balk, S.P. Clonal progression of prostate cancers from Gleason grade 3 to grade 4. Cancer Res. 2013, 73, 1050-1055.

77. Liong, M.L.; Lim, C.R.; Yang, H.; Chao, S.; Bong, C.W.; Leong, W.S.; Das, P.K.; Loh, C.S.; Lau, B.E.; Yu, C.G.; et al. Blood-based biomarkers of aggressive prostate cancer. PLoS One 2012, doi:10.1371/journal.pone.0045802. 
78. Voutsadakis, I.A.; Vlachostergios, P.J.; Daliani, D.D.; Karasavvidou, F.; Kakkas, G.; Moutzouris, G.; Melekos, M.D.; Papandreou, C.N. CD10 is inversely associated with nuclear factor-kappa B and predicts biochemical recurrence after radical prostatectomy. Urol. Int. 2012, 88, 158-164.

79. Fleischmann, A.; Rocha, C.; Saxer-Sekulic, N.; Zlobec, I.; Sauter, G.; Thalmann, G.N. High CD10 expression in lymph node metastases from surgically treated prostate cancer independently predicts early death. Virchows Arch. 2011, 458, 741-748.

80. Fleischmann, A.; Schlomm, T.; Huland, H.; Kollermann, J.; Simon, P.; Mirlacher, M.; Salomon, G.; Chun, F.H.; Steuber, T.; Simon, R.; et al. Distinct subcellular expression patterns of neutral endopeptidase (CD10) in prostate cancer predict diverging clinical courses in surgically treated patients. Clin. Cancer Res. 2008, 14, 7838-7842.

81. Xu, L.L.; Sun, C.; Petrovics, G.; Makarem, M.; Furusato, B.; Zhang, W.; Sesterhenn, I.A.; McLeod, D.G.; Sun, L.; Moul, J.W.; et al. Quantitative expression profile of PSGR in prostate cancer. Prostate Cancer Prostatic Dis. 2006, 9, 56-61.

82. Romero, D.; O’Neill, C.; Terzic, A.; Contois, L.; Young, K.; Conley, B.A.; Bergan, R.C.; Brooks, P.C.; Vary, C.P. Endoglin regulates cancer-stromal cell interactions in prostate tumors. Cancer Res. 2011, 71, 3482-3493.

83. Svatek, R.S.; Karam, J.A.; Roehrborn, C.G.; Karakiewicz, P.I.; Slawin, K.M.; Shariat, S.F. Preoperative plasma endoglin levels predict biochemical progression after radical prostatectomy. Clin. Cancer Res. 2008, 14, 3362-3366.

84. Fujita, K.; Ewing, C.M.; Chan, D.Y.; Mangold, L.A.; Partin, A.W.; Isaacs, W.B.; Pavlovich, C.P. Endoglin (CD105) as a urinary and serum marker of prostate cancer. Int. J. Cancer 2009, 124, 664-669.

85. Pircher, A.; Hilbe, W.; Heidegger, I.; Drevs, J.; Tichelli, A.; Medinger, M. Biomarkers in tumor angiogenesis and anti-angiogenic therapy. Int. J. Mol. Sci. 2011, 12, 7077-7099.

86. Feneley, M.R.; Jan, H.; Granowska, M.; Mather, S.J.; Ellison, D.; Glass, J.; Coptcoat, M.; Kirby, R.S.; Ogden, C.; Oliver, R.T.; et al. Imaging with prostate-specific membrane antigen (PSMA) in prostate cancer. Prostate Cancer Prostatic Dis. 2000, 3, 47-52.

87. Ghosh, A.; Heston, W.D. Tumor target prostate specific membrane antigen (PSMA) and its regulation in prostate cancer. J. Cell Biochem. 2004, 91, 528-539.

88. Freeman, M.R.; Yang, W.; Di Vizio, D. Caveolin-1 and prostate cancer progression. Adv. Exp. Med. Biol. 2012, 729, 95-110.

89. Gumulec, J.; Sochor, J.; Hlavna, M.; Sztalmachova, M.; Krizkova, S.; Babula, P.; Hrabec, R.; Rovny, A.; Adam, V.; Eckschlager, T.; et al. Caveolin-1 as a potential high-risk prostate cancer biomarker. Oncol. Rep. 2012, 27, 831-841.

90. Guo, Y.; Xu, F.; Lu, T.; Duan, Z.; Zhang, Z. Interleukin-6 signaling pathway in targeted therapy for cancer. Cancer Treat. Rev. 2012, 7, 904-910.

91. Han, Z.D.; Bi, X.C.; Qin, W.J.; He, H.C.; Dai, Q.S.; Zou, J.; Ye, Y.K.; Liang, Y.X.; Zeng, G.H.; Chen, Z.N.; et al. CD147 expression indicates unfavourable prognosis in prostate cancer. Pathol. Oncol. Res. 2009, 15, 369-374.

92. Zhong, W.D.; Liang, Y.X.; Lin, S.X.; Li, L.; He, H.C.; Bi, X.C.; Han, Z.D.; Dai, Q.S.; Ye, Y.K.; Chen, Q.B.; et al. Expression of CD147 is associated with prostate cancer progression. Int. J. Cancer 2012, 130, 300-308. 
93. Pertega-Gomes, N.; Vizcaino, J.R.; Miranda-Goncalves, V.; Pinheiro, C.; Silva, J.; Pereira, H.; Monteiro, P.; Henrique, R.M.; Reis, R.M.; Lopes, C.; et al. Monocarboxylate transporter 4 (MCT4) and CD147 overexpression is associated with poor prognosis in prostate cancer. BMC Cancer 2011, 11, doi:10.1186/1471-2407-11-312.

94. Donato, R. Intracellular and extracellular roles of S100 proteins. Microsc. Res. Tech. 2003, 60, 540-551.

95. Gupta, S.; Hussain, T.; MacLennan, G.T.; Fu, P.; Patel, J.; Mukhtar, H. Differential expression of S100A2 and S100A4 during progression of human prostate adenocarcinoma. J. Clin. Oncol. 2003, 21, 106-112.

96. Rehman, I.; Azzouzi, A.R.; Cross, S.S.; Deloulme, J.C.; Catto, J.W.; Wylde, N.; Larre, S.; Champigneuille, J.; Hamdy, F.C. Dysregulated expression of S100A11 (calgizzarin) in prostate cancer and precursor lesions. Hum Pathol. 2004, 35, 1385-1391.

97. Rehman, I.; Cross, S.S.; Catto, J.W.; Leiblich, A.; Mukherjee, A.; Azzouzi, A.R.; Leung, H.Y.; Hamdy, F.C. Promoter hyper-methylation of calcium binding proteins S100A6 and S100A2 in human prostate cancer. Prostate 2005, 65, 322-330.

98. Hermani, A.; Hess, J.; De Servi, B.; Medunjanin, S.; Grobholz, R.; Trojan, L.; Angel, P.; Mayer, D. Calcium-binding proteins S100A8 and S100A9 as novel diagnostic markers in human prostate cancer. Clin. Cancer Res. 2005, 11, 5146-5152.

99. Kollermann, J.; Schlomm, T.; Bang, H.; Schwall, G.P.; von Eichel-Streiber, C.; Simon, R.; Schostak, M.; Huland, H.; Berg, W.; Sauter, G.; et al. Expression and prognostic relevance of annexin A3 in prostate cancer. Eur. Urol. 2008, 54, 1314-1323.

100. Leman, E.S.; Getzenberg, R.H. Biomarkers for prostate cancer. J. Cell Biochem. 2009, 108, 3-9.

101. Gerke, V.; Creutz, C.E.; Moss, S.E. Annexins: Linking $\mathrm{Ca}^{2+}$ signalling to membrane dynamics. Nat. Rev. Mol. Cell Biol. 2005, 6, 449-461.

102. Pisitkun, T.; Shen, R.F.; Knepper, M.A. Identification and proteomic profiling of exosomes in human urine. Proc. Natl. Acad. Sci. USA 2004, 101, 13368-13373.

103. Schostak, M.; Schwall, G.P.; Poznanovic, S.; Groebe, K.; Muller, M.; Messinger, D.; Miller, K.; Krause, H.; Pelzer, A.; Horninger, W.; et al. Annexin A3 in urine: A highly specific noninvasive marker for prostate cancer early detection. J. Urol. 2009, 181, 343-353.

104. Kattan, M.W.; Shariat, S.F.; Andrews, B.; Zhu, K.; Canto, E.; Matsumoto, K.; Muramoto, M.; Scardino, P.T.; Ohori, M.; Wheeler, T.M.; et al. The addition of interleukin-6 soluble receptor and transforming growth factor betal improves a preoperative nomogram for predicting biochemical progression in patients with clinically localized prostate cancer. J. Clin. Oncol. 2003, 21, 3573-3579.

105. Shariat, S.F.; Shalev, M.; Menesses-Diaz, A.; Kim, I.Y.; Kattan, M.W.; Wheeler, T.M.; Slawin, K.M. Preoperative plasma levels of transforming growth factor beta(1) (TGF-beta(1)) strongly predict progression in patients undergoing radical prostatectomy. J. Clin. Oncol. 2001, 19, 2856-2864.

106. Morton, D.M.; Barrack, E.R. Modulation of transforming growth factor beta 1 effects on prostate cancer cell proliferation by growth factors and extracellular matrix. Cancer Res. 1995, 55, 2596-2602. 
107. Shariat, S.F.; Kattan, M.W.; Traxel, E.; Andrews, B.; Zhu, K.; Wheeler, T.M.; Slawin, K.M. Association of pre- and postoperative plasma levels of transforming growth factor beta(1) and interleukin 6 and its soluble receptor with prostate cancer progression. Clin. Cancer Res. 2004, 10, 1992-1999.

108. Avgeris, M.; Mavridis, K.; Scorilas, A. Kallikrein-related peptidases in prostate, breast, and ovarian cancers: From pathobiology to clinical relevance. Biol. Chem. 2012, 393, 301-317.

109. Gallagher, D.J.; Vijai, J.; Cronin, A.M.; Bhatia, J.; Vickers, A.J.; Gaudet, M.M.; Fine, S.; Reuter, V.; Scher, H.I.; Hallden, C.; et al. Susceptibility loci associated with prostate cancer progression and mortality. Clin. Cancer Res. 2010, 16, 2819-2832.

110. Harries, L.W.; Perry, J.R.; McCullagh, P.; Crundwell, M. Alterations in LMTK2, MSMB and HNF1B gene expression are associated with the development of prostate cancer. BMC Cancer 2010, 10, doi:10.1186/1471-2407-10-315.

111. FitzGerald, L.M.; Zhang, X.; Kolb, S.; Kwon, E.M.; Liew, Y.C.; Hurtado-Coll, A.; Knudsen, B.S.; Ostrander, E.A.; Stanford, J.L. Investigation of the relationship between prostate cancer and MSMB and NCOA4 genetic variants and protein expression. Hum. Mutat. 2013, 34, 149-156.

112. Huang, P.Y.; Best, O.G.; Belov, L.; Mulligan, S.P.; Christopherson, R.I. Surface profiles for subclassification of chronic lymphocytic leukemia. Leuk. Lymphoma 2012, 53, 1046-1056.

113. Choudhury, A.D.; Eeles, R.; Freedland, S.J.; Isaacs, W.B.; Pomerantz, M.M.; Schalken, J.A.; Tammela, T.L.; Visakorpi, T. The role of genetic markers in the management of prostate cancer. Eur. Urol. 2012, 4, 577-587.

114. Eeles, R.A.; Olama, A.A.; Benlloch, S.; Saunders, E.J.; Leongamornlert, D.A.; Tymrakiewicz, M.; Ghoussaini, M.; Luccarini, C.; Dennis, J.; Jugurnauth-Little, S.; et al. Identification of 23 new prostate cancer susceptibility loci using the iCOGS custom genotyping array. Nat. Genet. 2013, 45, 385-391.

115. Salagierski, M.; Schalken, J.A. Molecular diagnosis of prostate cancer: PCA3 and TMPRSS2:ERG gene fusion. J. Urol. 2012, 187, 795-801.

116. Van Gils, M.P.; Hessels, D.; van Hooij, O.; Jannink, S.A.; Peelen, W.P.; Hanssen, S.L.; Witjes, J.A.; Cornel, E.B.; Karthaus, H.F.; Smits, G.A.; et al. The time-resolved fluorescence-based PCA3 test on urinary sediments after digital rectal examination; a Dutch multicenter validation of the diagnostic performance. Clin. Cancer Res. 2007, 13, 939-943.

117. King, J.C.; Xu, J.; Wongvipat, J.; Hieronymus, H.; Carver, B.S.; Leung, D.H.; Taylor, B.S.; Sander, C.; Cardiff, R.D.; Couto, S.S.; et al. Cooperativity of TMPRSS2-ERG with PI3-kinase pathway activation in prostate oncogenesis. Nat. Genet. 2009, 41, 524-526.

118. Hessels, D.; Smit, F.P.; Verhaegh, G.W.; Witjes, J.A.; Cornel, E.B.; Schalken, J.A. Detection of TMPRSS2-ERG fusion transcripts and prostate cancer antigen 3 in urinary sediments may improve diagnosis of prostate cancer. Clin. Cancer Res. 2007, 13, 5103-5108.

119. Salami, S.S.; Schmidt, F.; Laxman, B.; Regan, M.M.; Rickman, D.S.; Scherr, D.; Bueti, G.; Siddiqui, J.; Tomlins, S.A.; Wei, J.T.; et al. Combining urinary detection of TMPRSS2:ERG and PCA3 with serum PSA to predict diagnosis of prostate cancer. Urol. Oncol. 2011, doi:10.1016/j.urolonc.2011.04.001. 
120. Saramaki, O.R.; Harjula, A.E.; Martikainen, P.M.; Vessella, R.L.; Tammela, T.L.; Visakorpi, T. TMPRSS2:ERG fusion identifies a subgroup of prostate cancers with a favorable prognosis. Clin. Cancer Res. 2008, 14, 3395-3400.

121. De Muga, S.; Hernandez, S.; Salido, M.; Lorenzo, M.; Agell, L.; Juanpere, N.; Lorente, J.A.; Serrano, S.; Lloreta, J. CXCR4 mRNA overexpression in high grade prostate tumors: Lack of association with TMPRSS2-ERG rearrangement. Cancer Biomark. 2012, 12, 21-30.

122. Du Pasquier, L. Innate immunity in early chordates and the appearance of adaptive immunity. Comptes Rendus Biol. 2004, 327, 591-601.

123. Yeh, J.H.; Sidhu, S.S.; Chan, A.C. Regulation of a late phase of T cell polarity and effector functions by Crtam. Cell 2008, 132, 846-859.

124. Roth, C.; Schuierer, M.; Gunther, K.; Buettner, R. Genomic structure and DNA binding properties of the human zinc finger transcriptional repressor AP-2rep (KLF12). Genomics 2000, 63, 384-390.

125. Catto, J.W.; Alcaraz, A.; Bjartell, A.S.; De Vere White, R.; Evans, C.P.; Fussel, S.; Hamdy, F.C.; Kallioniemi, O.; Mengual, L.; Schlomm, T.; et al. MicroRNA in prostate, bladder, and kidney cancer: A systematic review. Eur. Urol. 2011, 59, 671-681.

126. Catto, J.W.; Miah, S.; Owen, H.C.; Bryant, H.; Myers, K.; Dudziec, E.; Larre, S.; Milo, M.; Rehman, I.; Rosario, D.J.; et al. Distinct microRNA alterations characterize high- and low-grade bladder cancer. Cancer Res. 2009, 69, 8472-8481.

127. Bartel, D.P. MicroRNAs: Target recognition and regulatory functions. Cell 2009, 136, 215-233.

128. Ilic, D.; Neuberger, M.M.; Djulbegovic, M.; Dahm, P. Screening for prostate cancer. Cochrane Database Syst. Rev. 2013, doi:10.1002/14651858.CD004720.pub3.

129. Nikitina, E.G.; Urazova, L.N.; Stegny, V.N. MicroRNAs and human cancer. Exp. Oncol. 2012, $34,2-8$.

130. Sun, T.; Wang, Q.; Balk, S.; Brown, M.; Lee, G.S.; Kantoff, P. The role of microRNA-221 and microRNA-222 in androgen-independent prostate cancer cell lines. Cancer Res. 2009, 69, 3356-3363.

131. Meng, F.; Henson, R.; Wehbe-Janek, H.; Ghoshal, K.; Jacob, S.T.; Patel, T. MicroRNA-21 regulates expression of the PTEN tumor suppressor gene in human hepatocellular cancer. Gastroenterology 2007, 133, 647-658.

132. Dabir, P.D.; Ottosen, P.; Hoyer, S.; Hamilton-Dutoit, S. Comparative analysis of three- and two-antibody cocktails to AMACR and basal cell markers for the immunohistochemical diagnosis of prostate carcinoma. Diagn. Pathol. 2012, 7, doi:10.1186/1746-1596-7-81.

133. Shariat, S.F.; Scherr, D.S.; Gupta, A.; Bianco, F.J., Jr.; Karakiewicz, P.I.; Zeltser, I.S.; Samadi, D.B.; Akhavan, A. Emerging biomarkers for prostate cancer diagnosis, staging, and prognosis. Arch. Esp. Urol. 2011, 64, 681-694.

134. Jiang, Z.; Fanger, G.R.; Woda, B.A.; Banner, B.F.; Algate, P.; Dresser, K.; Xu, J.; Chu, P.G. Expression of alpha-methylacyl-CoA racemase (P504s) in various malignant neoplasms and normal tissues: Astudy of 761 cases. Hum. Pathol. 2003, 34, 792-796.

135. Sreekumar, A.; Laxman, B.; Rhodes, D.R.; Bhagavathula, S.; Harwood, J.; Giacherio, D.; Ghosh, D.; Sanda, M.G.; Rubin, M.A.; Chinnaiyan, A.M. Humoral immune response to alpha-methylacyl-CoA racemase and prostate cancer. J. Natl. Cancer Inst. 2004, 96, 834-843. 
136. Prensner, J.R.; Rubin, M.A.; Wei, J.T.; Chinnaiyan, A.M. Beyond PSA: The next generation of prostate cancer biomarkers. Sci. Transl. Med. 2012, 4, doi:10.1126/scitranslmed.3003180.

137. Ouyang, B.; Leung, Y.K.; Wang, V.; Chung, E.; Levin, L.; Bracken, B.; Cheng, L.; Ho, S.M. Alpha-Methylacyl-CoA racemase spliced variants and their expression in normal and malignant prostate tissues. Urology 2011, 77, 241-247.

138. Lloyd, M.D.; Yevglevskis, M.; Lee, G.L.; Wood, P.J.; Threadgill, M.D.; Woodman, T.J. Alpha-Methylacyl-CoA racemase (AMACR): Metabolic enzyme, drug metabolizer and cancer marker P504S. Prog. Lipid Res. 2013, 52, 220-230.

139. Rubin, M.A.; Bismar, T.A.; Andren, O.; Mucci, L.; Kim, R.; Shen, R.; Ghosh, D.; Wei, J.T.; Chinnaiyan, A.M.; Adami, H.O.; et al. Decreased alpha-methylacyl CoA racemase expression in localized prostate cancer is associated with an increased rate of biochemical recurrence and cancer-specific death. Cancer Epidemiol. Biomark. Prev. 2005, 14, 1424-1432.

140. Saedi, M.S.; Zhu, Z.; Marker, K.; Liu, R.S.; Carpenter, P.M.; Rittenhouse, H.; Mikolajczyk, S.D. Human kallikrein 2 (hK2), but not prostate-specific antigen (PSA), rapidly complexes with protease inhibitor 6 (PI-6) released from prostate carcinoma cells. Int. J. Cancer 2001, 94, 558-563.

141. Potter, S.R.; Partin, A.W. Tumor markers: An update on human kallikrein 2. Rev. Urol. 2000, 2, 221-222.

142. Recker, F.; Kwiatkowski, M.K.; Piironen, T.; Pettersson, K.; Huber, A.; Lummen, G.; Tscholl, R. Human glandular kallikrein as a tool to improve discrimination of poorly differentiated and non-organ-confined prostate cancer compared with prostate-specific antigen. Urology 2000, 55, $481-485$.

143. Steuber, T.; Vickers, A.J.; Haese, A.; Becker, C.; Pettersson, K.; Chun, F.K.; Kattan, M.W.; Eastham, J.A.; Scardino, P.T.; Huland, H.; et al. Risk assessment for biochemical recurrence prior to radical prostatectomy: Significant enhancement contributed by human glandular kallikrein 2 (hK2) and free prostate specific antigen (PSA) in men with moderate PSA-elevation in serum. Int. J. Cancer 2006, 118, 1234-1240.

144. Morgan, R.; Boxall, A.; Bhatt, A.; Bailey, M.; Hindley, R.; Langley, S.; Whitaker, H.C.; Neal, D.E.; Ismail, M.; Whitaker, H.; et al. Engrailed-2 (EN2): A tumor specific urinary biomarker for the early diagnosis of prostate cancer. Clin. Cancer Res. 2011, 17, 1090-1098.

145. Bose, S.K.; Bullard, R.S.; Donald, C.D. Oncogenic role of engrailed-2 (en-2) in prostate cancer cell growth and survival. Transl. Oncogenomics 2008, 3, 37-43.

146. Pandha, H.; Sorensen, K.D.; Orntoft, T.F.; Langley, S.; Hoyer, S.; Borre, M.; Morgan, R. Urinary engrailed-2 (EN2) levels predict tumour volume in men undergoing radical prostatectomy for prostate cancer. BJU Int. 2012, 110, 287-292.

147. Launay, G.; Teletchea, S.; Wade, F.; Pajot-Augy, E.; Gibrat, J.F.; Sanz, G. Automatic modeling of mammalian olfactory receptors and docking of odorants. Protein Eng. Des. Sel. 2012, 25, 377-386.

148. Wang, X.; Yu, J.; Sreekumar, A.; Varambally, S.; Shen, R.; Giacherio, D.; Mehra, R.; Montie, J.E.; Pienta, K.J.; Sanda, M.G.; et al. Autoantibody signatures in prostate cancer. N. Engl. J. Med. 2005, 353, 1224-1235.

149. Massoner, P.; Lueking, A.; Goehler, H.; Hopfner, A.; Kowald, A.; Kugler, K.G.; Amersdorfer, P.; Horninger, W.; Bartsch, G.; Schulz-Knappe, P.; et al. Serum-autoantibodies for discovery of prostate cancer specific biomarkers. Prostate 2012, 72, 427-436. 
150. Barber, N.; Gez, S.; Belov, L.; Mulligan, S.P.; Woolfson, A.; Christopherson, R.I. Profiling CD antigens on leukaemias with an antibody microarray. FEBS Lett. 2009, 583, 1785-1791.

151. Belov, L.; Huang, P.; Chrisp, J.S.; Mulligan, S.P.; Christopherson, R.I. Screening microarrays of novel monoclonal antibodies for binding to T-, B- and myeloid leukaemia cells. J. Immunol. Methods 2005, 305, 10-19.

152. Kaufman, K.L.; Belov, L.; Huang, P.; Mactier, S.; Scolyer, R.A.; Mann, G.J.; Christopherson, R.I. An extended antibody microarray for surface profiling metastatic melanoma. J. Immunol. Methods 2010, 358, 23-34.

153. Lal, S.; Brown, A.; Nguyen, L.; Braet, F.; Dyer, W.; Dos Remedios, C. Using antibody arrays to detect microparticles from acute coronary syndrome patients based on cluster of differentiation (CD) antigen expression. Mol. Cell Proteomics 2009, 8, 799-804.

154. Zhou, J.; Belov, L.; Huang, P.Y.; Shin, J.S.; Solomon, M.J.; Chapuis, P.H.; Bokey, L.; Chan, C.; Clarke, C.; Clarke, S.J.; et al. Surface antigen profiling of colorectal cancer using antibody microarrays with fluorescence multiplexing. J. Immunol. Methods 2010, 355, 40-51.

155. Wu, J.Q.; Wang, B.; Belov, L.; Chrisp, J.; Learmont, J.; Dyer, W.B.; Zaunders, J.; Cunningham, A.L.; Dwyer, D.E.; Saksena, N.K. Antibody microarray analysis of cell surface antigens on $\mathrm{CD} 4+$ and $\mathrm{CD} 8+\mathrm{T}$ cells from $\mathrm{HIV}+$ individuals correlates with disease stages. Retrovirology 2007, 4, doi:10.1186/1742-4690-4-83.

156. Jiao, J.; Hindoyan, A.; Wang, S.; Tran, L.M.; Goldstein, A.S.; Lawson, D.; Chen, D.; Li, Y.; Guo, C.; Zhang, B.; et al. Identification of CD166 as a Surface Marker for Enriching Prostate Stem/Progenitor and Cancer Initiating Cells. PLoS One 2012, 7, doi:10.1371/journal.pone.0042564.

157. Hao, J.; Madigan, M.C.; Khatri, A.; Power, C.A.; Hung, T.T.; Beretov, J.; Chang, L.; Xiao, W.; Cozzi, P.J.; Graham, P.H.; et al. In Vitro and In Vivo Prostate Cancer Metastasis and Chemoresistance Can Be Modulated by Expression of either CD44 or CD147. PLoS One 2012, 7, doi:10.1371/journal.pone.0040716.

158. Gyorgy, B.; Szabo, T.G.; Pasztoi, M.; Pal, Z.; Misjak, P.; Aradi, B.; Laszlo, V.; Pallinger, E.; Pap, E.; Kittel, A.; et al. Membrane vesicles, current state-of-the-art: Emerging role of extracellular vesicles. Cell Mol. Life Sci. 2011, 68, 2667-2688.

159. Duijvesz, D.; Luider, T.; Bangma, C.H.; Jenster, G. Exosomes as biomarker treasure chests for prostate cancer. Eur. Urol. 2011, 59, 823-831.

160. Nepple, K.G.; Wahls, T.L.; Hillis, S.L.; Joudi, F.N. Gleason Score and Laterality Concoordance Between Prostate Biopsy and Prostatectomy Specimens. Int. J. Braz. Urol. 2009, 35, 559-564

161. Yang, C.; Robbins, P.D. The roles of tumor-derived exosomes in cancer pathogenesis. Clin. Dev. Immunol. 2011, doi:10.1155/2011/842849.

162. Yang, Y.; Xiu, F.; Cai, Z.; Wang, J.; Wang, Q.; Fu, Y.; Cao, X. Increased induction of antitumor response by exosomes derived from interleukin-2 gene-modified tumor cells. J. Cancer Res. Clin. Oncol. 2007, 133, 389-399.

163. Ludwig, A.K.; Giebel, B. Exosomes: Small vesicles participating in intercellular communication. Int. J. Biochem. Cell Biol. 2012, 44, 11-15.

164. Ristorcelli, E.; Beraud, E.; Verrando, P.; Villard, C.; Lafitte, D.; Sbarra, V.; Lombardo, D.; Verine, A. Human tumor nanoparticles induce apoptosis of pancreatic cancer cells. FASEB $\mathbf{2 0 0 8}$, $22,3358-3369$. 
165. Wood, S.L.; Knowles, M.A.; Thompson, D.; Selby, P.J.; Banks, R.E. Proteomic studies of urinary biomarkers for prostate, bladder and kidney cancers. Nat. Rev. Urol. 2013, 10, 206-218.

166. Delcayre, A.; Shu, H.; Le Pecq, J.B. Dendritic cell-derived exosomes in cancer immunotherapy: Exploiting nature's antigen delivery pathway. Expert Rev. Anticancer Ther. 2005, 5, 537-547.

167. Thery, C.; Boussac, M.; Veron, P.; Ricciardi-Castagnoli, P.; Raposo, G.; Garin, J.; Amigorena, S. Proteomic analysis of dendritic cell-derived exosomes: A secreted subcellular compartment distinct from apoptotic vesicles. J. Immunol. 2001, 166, 7309-7318.

168. Ronquist, G.; Brody, I. The prostasome: Its secretion and function in man. Biochim. Biophys. Acta 1985, 822, 203-218.

169. Ronquist, G.; Nilsson, B.O. The Janus-faced nature of prostasomes: Their pluripotency favours the normal reproductive process and malignant prostate growth. Prostate Cancer Prostatic Dis. 2004, 7, 21-31.

170. Tavoosidana, G.; Ronquist, G.; Darmanis, S.; Yan, J.; Carlsson, L.; Wu, D.; Conze, T.; Ek, P.; Semjonow, A.; Eltze, E.; et al. Multiple recognition assay reveals prostasomes as promising plasma biomarkers for prostate cancer. Proc. Natl. Acad. Sci. USA 2011, 108, 8809-8814.

171. Saez, F.; Frenette, G.; Sullivan, R. Epididymosomes and prostasomes: Their roles in posttesticular maturation of the sperm cells. J. Androl. 2003, 24, 149-154.

172. Oon, S.F.; Pennington, S.R.; Fitzpatrick, J.M.; Watson, R.W. Biomarker research in prostate cancer-Towards utility, not futility. Nat. Rev. Urol. 2011, 8, 131-138.

173. Ronquist, G. Prostasomes are mediators of intercellular communication: From basic research to clinical implications. J. Int. Med. 2012, 271, 400-413.

174. Sahlen, G.E.; Egevad, L.; Ahlander, A.; Norlen, B.J.; Ronquist, G.; Nilsson, B.O. Ultrastructure of the secretion of prostasomes from benign and malignant epithelial cells in the prostate. Prostate 2002, 53, 192-199.

175. Olmos, D.; Baird, R.D.; Yap, T.A.; Massard, C.; Pope, L.; Sandhu, S.K.; Attard, G.; Dukes, J.; Papadatos-Pastos, D.; Grainger, P.; et al. Baseline circulating tumor cell counts significantly enhance a prognostic score for patients participating in phase I oncology trials. Clin. Cancer Res. 2011, 17, 5188-5196.

176. Attard, G.; de Bono, J.S. Utilizing circulating tumor cells: Challenges and pitfalls. Curr. Opin. Genet. Dev. 2011, 21, 50-58.

177. Shaffer, D.R.; Leversha, M.A.; Danila, D.C.; Lin, O.; Gonzalez-Espinoza, R.; Gu, B.; Anand, A.; Smith, K.; Maslak, P.; Doyle, G.V.; et al. Circulating tumor cell analysis in patients with progressive castration-resistant prostate cancer. Clin. Cancer Res. 2007, 13, 2023-2029.

178. Bednarz-Knoll, N.; Alix-Panabieres, C.; Pantel, K. Clinical relevance and biology of circulating tumor cells. Breast Cancer Res. 2011, 13, doi:10.1186/bcr2940.

179. Laxman, B.; Morris, D.S.; Yu, J.; Siddiqui, J.; Cao, J.; Mehra, R.; Lonigro, R.J.; Tsodikov, A.; Wei, J.T.; Tomlins, S.A.; et al. A first-generation multiplex biomarker analysis of urine for the early detection of prostate cancer. Cancer Res. 2008, 68, 645-649.

(C) 2013 by the authors; licensee MDPI, Basel, Switzerland. This article is an open access article distributed under the terms and conditions of the Creative Commons Attribution license (http://creativecommons.org/licenses/by/3.0/). 